\title{
Ascl1/Mash1 Promotes Brain Oligodendrogenesis during Myelination and Remyelination
}

\author{
Hiroko Nakatani, ${ }^{1,2,3}$ Elodie Martin, ${ }^{1,2,3 *}$ Hessameh Hassani, ${ }^{1,2,3 *}$ Adrien Clavairoly, ${ }^{1,2,3}$ Cécile L. Maire, ${ }^{1,2,3}$ \\ Arthur Viadieu, ${ }^{1,2,3}$ Christophe Kerninon, ${ }^{1,2,3}$ Aurélie Delmasure, ${ }^{1,2,3}$ Magali Frah, ${ }^{1,2,3}$ Melanie Weber, ${ }^{4}$ \\ Masato Nakafuku, ${ }^{5}$ Bernard Zalc, ${ }^{1,2,3,6}$ Jean-Léon Thomas, ${ }^{1,2,3,6,7}$ François Guillemot, ${ }^{4}$ Brahim Nait-Oumesmar, ${ }^{1,2,3,6}$ \\ and Carlos Parras ${ }^{1,2,3}$ \\ ${ }^{1}$ Université Pierre et Marie Curie-Paris 6, Centre de Recherche de l'Institut du Cerveau et de la Moelle épinière, 75013 Paris, France, ${ }^{2}$ Inserm UMR_S 975, \\ 75013 Paris, France, ${ }^{3}$ Centre National de la Recherche Scientifique Unité Mixte de Recherche 7225, 75013 Paris, France, ${ }^{4}$ Medical Research Council National \\ Institute for Medical Research, Division of Molecular Neurobiology, London NW71 AA United Kingdom, ${ }^{5}$ Division of Developmental Biology, Cincinnati \\ Children's Hospital Research Foundation, Cincinnati, Ohio 45229, ${ }^{6}$ Assistance Publique-Hôpitaux de Paris, GH Pitié-Salpêtrière, 75013 Paris, France, and \\ ${ }^{7}$ Department of Neurology, Yale School of Medicine, New Haven, Connecticut 06511
}

Oligodendrocytes are the myelin-forming cells of the CNS. They differentiate from oligodendrocyte precursor cells (OPCs) that are produced from progenitors throughout life but more actively during the neonatal period and in response to demyelinating insults. An accurate regulation of oligodendrogenesis is required to generate oligodendrocytes during these developmental or repair processes. We hypothesized that this regulation implicates transcription factors, which are expressed by OPCs and/or their progenitors. Ascl1/Mash1 is a proneural transcription factor previously implicated in embryonic oligodendrogenesis and operating in genetic interaction with Olig2, an essential transcriptional regulator in oligodendrocyte development. Herein, we have investigated the contribution of Ascl1 to oligodendrocyte development and remyelination in the postnatal cortex. During the neonatal period, Ascl1 expression was detected in progenitors of the cortical subventricular zone and in cortical OPCs. Different genetic approaches to delete Ascll in cortical progenitors or OPCs reduced neonatal oligodendrogenesis, showing that Ascll positively regulated both OPC specification from subventricular zone progenitors as well as the balance between OPC differentiation and proliferation. Examination of remyelination processes, both in the mouse model for focal demyelination of the corpus callosum and in multiple sclerosis lesions in humans, indicated that Ascll activity was upregulated along with increased oligodendrogenesis observed in remyelinating lesions. Additional genetic evidence indicated that remyelinating oligodendrocytes derived from Ascl1 ${ }^{+}$ progenitors/OPCs and that Ascll was required for proper remyelination. Together, our results show that Ascll function modulates multiple steps of OPC development in the postnatal brain and in response to demyelinating insults.

\section{Introduction}

During development, the basic-helix-loop-helix transcription factor (TF) Olig2 is both necessary and, in some contexts, suffi-

Received Feb. 21, 2013; revised April 4, 2013; accepted April 13, 2013.

Author contributions: B.N.-O. and C.P. designed research; H.N., E.M., H.H., A.C., C.L.M., A.V., C.K., A.D., M.F., M.W., and C.P. performed research; M.N. contributed unpublished reagents/analytic tools; H.N., E.M., H.H., A.C., M.N., B.Z., J.-L.T., F.G., B.N.-O., and C.P. analyzed data; B.Z., J.-L.T., F.G., B.N.-O., and C.P. wrote the paper.

This work was supported by Institut National de la Santé et de la Recherche Médicale Grant R05245DS to C.P. and H.N., National Multiple Sclerosis Society RG 4318A1/1 to H.N. and E.M., Fondation pour l'Aide à la Recherche sur la Sclerose En Plaques (H.N., H.H.), Neuropôle de Recherche Francilien/Région de l'lle-de-France (H.H.), Fondation de France (C.P., H.N.), Université Pierre et Marie Curie-Paris 6 (A.C.), and "Investissements d'Avenir" ANR-10-IAIHU-06 at the Institut du Cerveau et de Moelleépinière (C.K., B.N.-0.). We thank Dr.W.D. Richardson for the PDGFR $\alpha$ ::CreERR ${ }^{T 2}$ mice; A. Chedotal, J. Johnson, K. Campbell, G. Panganiban, M. Okabe, and M. Wegner for reagents; the UK Multiple Sclerosis Tissue Bank (Pr R. Reynolds, Imperial College, London), funded by the Multiple Sclerosis Society of Great Britain and Northern Ireland, registered charity 207495, for brain tissue samples; and A. Dauphin and D. Langui from the Plate-forme d'Imagerie Cellulaire de la PitiéSalpêtrière for their advice, notably with EM analysis.

The authors declare no competing financial interests.

*E.M. and H.H. contributed equally to this work.

Correspondence should be addressed to Dr. Carlos Parras, Université Pierre et Marie Curie-Paris 6, Centre de Recherche de I'Institut du Cerveau et de la Moelle épinière, Hôpital de la Pitié-Salpêtrière 83, Boulevard de l'Hôpital ICM, 4ème étage (4.007), 75013 Paris, France. E-mail: carlos.parras@upmc.fr.

C.L. Maire's present address: Medical Oncology, Dana-Farber Cancer Institute, 44 Binney Street, Boston, MA 02115.

DOI:10.1523/JNEUROSCI.0805-13.2013

Copyright $\odot 2013$ the authors $\quad 0270-6474 / 13 / 339752-17 \$ 15.00 / 0$ cient for oligodendrocyte precursor cell (OPC) generation ( $\mathrm{Lu}$ et al., 2001; Zhou et al., 2001; Zhou and Anderson, 2002; Yue et al., 2006; Zhu et al., 2012). Despite this key role, Olig2 is however not a master gene, and it acts in concert with additional cofactors to regulate oligodendrocyte specification. For example, Olig2 must interact with signaling pathways controlling its phosphorylation state to acquire an oligodendrogenic activity (Li et al., 2011). The multiple focal pattern of oligodendrogenesis in the embryonic brain also suggests that Olig2 interacts with multiple TFs providing positional cues and regulating locally its action in progenitor cells (Spassky et al., 1998; Tekki-Kessaris et al., 2001; Miguez et al., 2012).

Ascl1 is another basic-helix-loop-helix factor playing a major role at different stages of neurogenesis and having potent proneural and reprogramming activities (Bertrand et al., 2002; Vierbuchen et al., 2010; Vierbuchen and Wernig, 2012). Ascl1 is also expressed by embryonic and neonatal OPCs (Kondo and Raff, 2000; Wang et al., 2001; Parras et al., 2004; Parras et al., 2007). Ascl1 operates in genetic interaction with Olig2 during OPC specification in the embryonic telencephalon, and the loss of Ascl1 function reduces embryonic oligodendrogenesis (Parras et al., 2007; Sugimori et al., 2007). Therefore, beyond its role in neurogenesis, Ascl1 is involved in the regulation of oligodendrogenesis. 
Table 1. Clinical and morphological characteristics of postmortem MS brain tissue

\begin{tabular}{|c|c|c|c|c|c|c|c|c|c|c|}
\hline \multirow[b]{2}{*}{ Case } & \multirow[b]{2}{*}{ Sex } & \multirow{2}{*}{$\begin{array}{l}\text { Age } \\
\text { (years) }\end{array}$} & \multirow{2}{*}{$\begin{array}{l}\text { PMD } \\
\text { (hours) }\end{array}$} & \multirow{2}{*}{$\begin{array}{l}\text { Disease } \\
\text { duration (years) }\end{array}$} & \multirow{2}{*}{$\begin{array}{l}\text { Cause } \\
\text { of death }\end{array}$} & \multirow[b]{2}{*}{ Course } & \multicolumn{4}{|c|}{ Lesions analyzed } \\
\hline & & & & & & & Active & Chronic active & Chronic silent & Shadow plaques \\
\hline \multicolumn{11}{|l|}{ MS } \\
\hline MS100 & M & 46 & 7 & 8 & Pneumonia & SP & 0 & 1 & 0 & 0 \\
\hline MS127 & M & 51 & 21 & 10 & MS, bronchopneumonia & SP & 1 & 1 & 0 & 0 \\
\hline MS136 & M & 50 & 10 & 9 & Respiratory failure, sepsis, MS & SP & 1 & 0 & 0 & 0 \\
\hline MS154 & $\mathrm{F}$ & 34 & 12 & 9 & Pneumonia & SP & 1 & 1 & 0 & 0 \\
\hline \multicolumn{11}{|l|}{ Control } \\
\hline $\mathrm{C} 20$ & $\mathrm{~F}$ & 84 & 24 & & Congestive cardiac failure & & 0 & 0 & 0 & 0 \\
\hline $\mathrm{CO} 2$ & $\mathrm{~F}$ & 95 & 10 & & Bronchopneumonia & & 0 & 0 & 0 & 0 \\
\hline
\end{tabular}

The importance of Ascl1 action in postnatal oligodendrogenesis and myelination as well as its requirement for proper myelin repair have however not yet been determined.

To ascertain its involvement in oligodendrogenesis during myelination and remyelination, we have examined Ascl1 expression and function in oligodendroglial cells during the postnatal period of development and during myelin repair in the adult brain. At all ages examined, Ascl1 expression was restricted to immature cell types (i.e., cortical subventricular zone [SVZ] progenitor cells and OPCs of gray matter and white matter). Using different genetic models to delete Ascl1 in progenitor cells or OPCs, and to trace the Ascl1-cell lineage, we have characterized Ascl1 requirement in oligodendrogenesis both under normal physiological conditions and after demyelinating lesions. We found that Ascl1 was required in SVZ progenitors for oligodendroglial cell fate decision as well as in OPCs for their proper differentiation into oligodendrocytes. After demyelinating lesions, Ascl1 was expressed by intralesional SVZ progenitors and OPCs, which regenerated myelin-forming cells and thus participated in myelin repair of demyelinated lesions. Although Ascl1 was dispensable for recruitment and maturation of intralesional progenitors and OPCs, we showed that it was required for a proper balance between the number of OPCs and oligodendrocytes. Finally, examination of human periventricular multiple sclerosis (MS) lesions confirmed that Ascl1 expression is a hallmark of OPCs involved in myelin repair, both in mice and humans. Together, our findings support a promoting role for Ascl1 during postnatal oligodendrogenesis and in the process of remyelination, both in progenitors for OPC specification as well as in OPCs for their differentiation.

\section{Materials and Methods}

Mouse breeding and genotyping. The following transgenic lines were used and genotyped using protocols previously described: $\mathrm{Ascll}^{\Delta}$ (Casarosa et al., 1999), Ascl1 $1^{f l}$ (Pacary et al., 2011), Ascl1::Cre, Ascll::GFP (Parras et al., 2007), Rosa26 ${ }^{\text {stop-YFP }}$ (Srinivas et al., 2001), Rosa26 ${ }^{\text {stop-LacZ }}$ (Soriano, 1999), and PDGFR $\alpha:: C r e E R^{T 2}$ (Rivers et al., 2008). For simplicity, we renamed the different mice as follows: $A s c l 1^{G F P}$ (for Ascl1::GFP), Ascl1 ${ }^{\text {Cre/YFP }}$ (for Ascl1::Cre; Rosa26 $6^{\text {stop-YFP }}$ ), Ascl1 Cre/LacZ (for Ascll::Cre; Rosa26 $6^{\text {stop-LacZ }}$ ), $C \mathrm{Ko}^{\mathrm{OPC}}$ (for conditional knock-out in OPCs: PDGFR $\alpha:: C r e E R^{T 2}$; Ascl1 $1^{f / \Delta}$; Rosa $26^{\text {stop-YFP }}$ ), Ctr ${ }^{O P C}$ (for control for $C k o^{O P C}:$ PDGFR $\alpha: \mathrm{CreER}^{T 2}$; Ascl1 ${ }^{\text {fl/ }}$; Rosa2 $6^{\text {stop-YFP }}$ ), Cko ${ }^{d S V Z}$ (for dorsal Cre-electroporated Ascl1 ${ }^{f l / \Delta}$; Rosa26 ${ }^{\text {stop-YFP }}$ ), and $\mathrm{Ctr}^{d S V Z}$ (for dorsal Cre-electroporated $\mathrm{Ascl}^{f l /+}$; Rosa26 $6^{\text {stop-YFP }}$ ). Both males and females were included in the study. All experiments were carried out in accordance to Inserm ethical committees (authorization \#A75-13-19) and personal animal experimentation license A75-17-72 (C.P.).

Demyelinating mouse lesions. Before surgery, adult (4-6 months) $A s c l 1{ }^{G F P}, A s c l 1^{\text {Cre/YFP }}$, amd Ascll Cre/LacZ or Cko/Ctr ${ }^{\text {OPC }}$ mice were weighted and anesthetized by intraperitoneal injection of mixture of ketamine $(0.1 \mathrm{mg} / \mathrm{g})$ and xylacine $(0.01 \mathrm{mg} / \mathrm{g})$. An analgesic (buprenorphine, $30 \mathrm{mg} / \mathrm{g}$ ) was administered intraperitoneally to prevent postsur- gical pain. Focal demyelinating lesions were induced by stereotaxic injection of $1.5 \mu$ l lysolecithin solution (LPC, Sigma, $1 \%$ in $0.9 \% \mathrm{NaCl}$ ) into the corpus callosum (CC; at coordinates: $1 \mathrm{~mm}$ lateral, $1.3 \mathrm{~mm}$ rostral to bregma, $1.7 \mathrm{~mm}$ deep to brain surface) using a glass-capillary connected to a $10 \mu \mathrm{l}$ Hamilton syringe. Animals were left to recover in a warm chamber before being returned into their housing cages.

Postnatal electroporation. Postnatal brain electroporation (Boutin et al., 2008) was adapted to target the dorsal SVZ. Briefly, postnatal day 2 (P2) pups were cryoanesthetized for $3 \mathrm{~min}$ on ice, and $2 \mu \mathrm{l}$ of plasmid solution ( $3 \mu \mathrm{g} p C X-C r e)$ was injected into the ventricle using a glass capillary. $p C X$-Cre plasmid drive Cre expression under the CMVmodified strong and ubiquitous promoter (kindly gift from Alain Chedotal, Institut de la Vision, Paris). Electrodes (Nepagene CUY650P10) were positioned in the dorsoventral axis with the positive pole dorsal. Five electric pulses of $100 \mathrm{~V}, 50 \mathrm{~ms}$ pulse ON, $850 \mathrm{~ms}$ pulse OFF were applied using a Nepagene CUY21-SC electroporator. Pups were immediately warmed up in a heating chamber and brought to their cages at the end of the experiment.

Tamoxifen administration. Tamoxifen (Sigma) was dissolved in corn oil (Sigma) at $20 \mathrm{mg} / \mathrm{ml}$. Postnatal mice received one subcutaneous injection of $400 \mu \mathrm{g}$ (P5) or one intraperitoneal injection of $800 \mu \mathrm{g}$ (P8/P9). Adult animals received one intraperitoneal injection per day of $200 \mu \mathrm{g}$ for 5 consecutive days starting $7 \mathrm{~d}$ before LPC lesion.

MS and non-neurological control tissues. Autopsy brain tissue samples from 4 patients with confirmed secondary progressive MS and two patients without neurological diseases (Table 1) were obtained from the United Kingdom MS tissue bank (Richards Reynolds, Imperial College, London). MS and control brain samples were excised from matching periventricular regions or white matter. Four MS tissue blocks containing active $(n=3)$ and chronic active lesions $(n=3)$, periventricular lesions, and periplaque white matter were selected for further analysis. MS lesions were classified as previously reported (Lassmann, 1998).

Electron microscopy. Ascl1 ${ }^{\text {Cre/LacZ }}$ mice (P120) were perfused with $4 \%$ PFA and $0.5 \%$ glutaraldehyde in PBS buffer. Brains were sectioned (300 $\mu \mathrm{m}$ ) with a Tissue chopper (McIlwain) and subjected overnight to the $\mathrm{X}$-gal reaction. Tissue was postfixed in $2.5 \%$ glutaraldehyde for $2 \mathrm{~h}$. Regions containing the CC were dissected out under a binocular scope (MZ16, Leica). Tissue samples were osmicated, dehydrated in ethanol, and embedded in Epon. Ultrathin sections were made using a Leica electronic microscopy (EM) UC7 ultramicrotome, and micrographs were taken with a Philips CM120 electronic microscope.

Immunofluorescence. We optimized immunostaining for Ascl1, which is very sensitive to fixation conditions. Mice were perfused with freshly made chilled $2 \%$ paraformaldehyde (Sigma) with the following amounts (P0-P10, 15 ml; P10-P16, 20 ml; adult, $25 \mathrm{ml}$ ), brain was dissected out, cryoprotected in PBS with $20 \%$ sucrose overnight, and included in OCT $(\mathrm{BDH})$ before freezing and sectioning $(14 \mu \mathrm{m}$ thick) with a cryostated microtome (Leica). Sections were then either processed for immunohistochemistry or stored at $-80^{\circ} \mathrm{C}$. P0-P16 brain sections were postfixed with $4 \%$ PFA for $10 \mathrm{~min}$. Sections were incubated in a blocking solution (PBS plus 10\% normal goat serum, Vector Laboratories; and 0.1\% Tween 20 or Triton X-100) and then with primary antibodies overnight at $4^{\circ} \mathrm{C}$. The following primary antibodies were used: mouse monoclonal antibodies to APC (Calbiochem, 1:200), Ascl1 (BD Biosciences, 1:200), CNP (Millipore, 1:500), MOG (8-18C5, 1:5, Dr. C. Linington, Max-Planck 
Institute, Tuebingen, Germany), Olig2 (Ligon et al., 2006), Nkx2.2 (clone 74.5A5, Developmental Studies Hybridoma Bank, 1:5); rabbit polyclonal antibodies to Caspase3 activated (R\&D Systems, 1:200), panDlx (gift from G. Panganiban, 1:100), GFP (Invitrogen, 1:2000), Gpr17 (Cayman Chemical, 1:400), Gsx2 (gift from K. Campbell, 1:1000), Ki67 (Novocastra, 1:1000), myelin basic protein (MBP, Millipore, 1:1000), NG2 (Millipore, 1:1000), Olig1 (Mizuguchi et al., 2001), Olig2 (Millipore, 1:1000), Sox9 (R\&D Systems, 1:500); guinea pig antibodies to Sox10 (gift from M. Wegner, 1:1000), Ascl1 (gift from J. Johnson, 1:1000); rat monoclonal antibodies to Ki67 (Dako, 1:50), PDGFR $\alpha$ (BD Biosciences, 1:800), and chicken polyclonal antibodies to GFP (Aves Laboratories, 1:2000) and MBP (Millipore, 1:50). Fluorescent secondary antibodies included the following: AlexaFluor-488, AlexaFluor-594, and AlexaFluor-647 Ig (1:1000, Invitrogen). Antigen retrieval for Ki67 antibody staining was performed using antigen retrieval solution (Vector, $\mathrm{H}-330$ ), heating sections in citrate-based solution up to boiling and then allowing cooling down at room temperature for $20 \mathrm{~min}$. Immunofluorescence was visualized with Leica TC SP2 confocal or Zeiss AxioImagerApotome system microscopes. Pictures were taken as stacks of 5-10 $\mu \mathrm{m}$ with $0.5 \mu \mathrm{m}$ between sections. Z-projections and orthogonal projections were done in ImageJ and processed with Adobe Photoshop. Figures were made using Adobe Illustrator.

Human brain tissues were immunostained as previously described (Nait-Oumesmar et al., 2007) with mouse monoclonal antibodies for human Ascl1 (Cosmo Bio, 1:500), CD68 (clone KP1, Dako, 1:100), rabbit antibodies for Olig2 (Millipore, 1:100), Olig1 (R\&D Systems, 1:50), and goat antibody for Sox10 (R\&D Systems, 1:50).

Quantification and statistical analysis. Confocal images were quantified for expression of TFs by manual or automated counting using Image J software. To quantify Ascll staining intensity at different stages studied (P2, P14, adult control, and adult $5 \mathrm{~d}$ after LPC lesion), confocal pictures of brain sections, immunolabeled for Ascll and PDGFR $\alpha$, were analyzed with ImageJ software to measure the mean nuclear Ascll intensity in CC OPCs (PDGFR $\alpha^{+}$cells) versus SVZ (PDGFR $\alpha^{-}$cells). Mean and SEM values obtained counting several sections $(n=3-5)$ are shown as the ratio of Ascll intensity in CC OPCs versus SVZ cells. To estimate levels of TF expression at different stages of OPC differentiation, mean values of their relative intensity in cells at each stage were obtained using ImageJ from images $(n=3)$, such as those shown in Figure 2. Data are presented as a line chart in Figure 2J. Values range from 0 to 255, with values $<50$ considered as background levels. All values are shown as mean \pm SEM. Statistical analysis was performed using Student's $t$ test in Prism 4, GraphPad Software. $p$ values in graphic are represented as follows: ${ }^{*} p<0.05,{ }^{* *} p<0.01,{ }^{* *} p<0.001$. Black bars in histograms correspond to SEM.

\section{Results}

\section{Immature oligodendroglial cells of neonatal cortex express Ascl1}

Although Ascl1 is required for OPC generation in the embryonic forebrain and spinal cord (Parras et al., 2007; Sugimori et al., 2007), its roles during neonatal oligodendrogenesis and myelination are currently unknown. Postnatal OPCs derive from the cortical wall of lateral ventricles both in neonates (Gorski et al., 2002; Ivanova et al., 2003; Kessaris et al., 2006) and adults (Menn et al., 2006). To address Ascl1 function in postnatal oligodendrogenesis and myelination, we first examined its cortical expression in newborn mice (P2) by immunofluorescence. Ascll was detected in subsets of cells located in the cortical ventricle wall and in the CC ( $\sim 15 \%$ and $25 \%$ of total cells, respectively). The phenotype of Ascl1-expressing cells was characterized using antibodies against TFs expressed by oligodendroglial progenitors and precursors, including Olig1, Olig2, Sox9, Sox10, and Nkx2.2 (Qi et al., 2001; Sun et al., 2001; Zhou et al., 2001; Zhou and Anderson, 2002; Stolt et al., 2003, 2004; Arnett et al., 2004; Kitada and Rowitch, 2006; Liu et al., 2007; Cai et al., 2010). In the dorsal ventricle wall, Ascl1 ${ }^{+}$cells expressed Olig2 (85\%; Fig. $\left.1 A, G\right)$ and
Sox9 ( $80 \%$; Fig. 1C,G), two TFs expressed by immature neural progenitor/stem cells (Hack et al., 2004; Scott et al., 2010). The majority of $\mathrm{Ascl}^{+} / \mathrm{Olig} 2^{+} / \mathrm{Sox} 9^{+}$cells expressed neither PDGFR $\alpha$, the most specific marker for OPCs (Hall et al., 1996; Kessaris et al., 2006), nor other OPC markers, such as NG2 (data not shown), or TFs expressed in OPCs, such as Olig1, Sox10, and Nkx2.2 TFs (Fig. 1B,D,E, G). In the CC, however, Ascl ${ }^{+}$cells included equal populations $(\sim 50 \%)$ of $\mathrm{Olig}^{+} / \mathrm{Sox}^{+} /$ PDGFR $\alpha^{-}$progenitor cells (Fig. $1 A-E, G$ ) and PDGFR $\alpha^{+}$cells (Fig. 1G,H). It is noteworthy that all Ascl1 ${ }^{+} / \mathrm{PDGFR} \alpha^{+}$cells ( $\sim 10 \%$ of CC cells and $\sim 2 \%$ of SVZ cells) also expressed Olig2 (Fig. $1 A, G, H$ ) and both nuclear and cytoplasmic Olig1 (Fig. $1 B, G, H$ ), as well as Sox10 (Fig. $1 D, G, H$ ), Nkx2.2 (Fig. $1 E, G, H$ ), and Sox9 (Fig. $1 C, C_{1}, H$ ). This phenotype suggests that all Ascl $1^{+} / \mathrm{PDGFR} \alpha^{+}$cells are OPCs and a fraction of $\mathrm{Ascl} 1^{+} /$ $\operatorname{PDGFR} \alpha^{-}$cells may correspond to immature neural progenitors in the process of generating OPCs (Fig. 1G,H). Supporting this possibility, we found that $\sim 48 \%$ of $\mathrm{Ascl} 1^{+} / \mathrm{PDGFR} \alpha{ }^{-}$cells do not express either Dlx or Gsx2, two neurogenic cofactors (Petryniak et al., 2007; Waclaw et al., 2009) that are not expressed in OPCs (Fig. $1 F-H$ ). Therefore, Ascl $1^{+} /$Olig2 ${ }^{+} / \mathrm{PDGFR} \alpha^{-}$/ $\mathrm{Dlx}^{-} / \mathrm{Gsx} 2^{-}$cells (corresponding to $5-7 \%$ of SVZ or CC cells) are likely immature oligodendroglial cells.

\section{Ascl1 in OPC is downregulated upon oligodendrocyte differentiation}

We then investigated Ascll expression during OPC transition into myelinating oligodendrocytes. In the CC, when many OPCs start to differentiate during the second postnatal week, Ascl1 is still expressed in all PDGFR $\alpha^{+}$OPCs (Fig. 2A), but APC/CC1expressing maturing oligodendrocytes (Bhat et al., 1996) were rarely Ascl1 ${ }^{+}$(Fig. 2 B, $B_{1}$ ) suggesting that maturing OPCs downregulate Ascll expression. Indeed, using the Ascl1 ${ }^{\text {GFP }}$ transgenic line, in which GFP remains expressed longer than Ascl1, we found that most $\mathrm{APC}^{+}$cells at this stage were $\mathrm{GFP}^{+}$(Fig. 2B).

To assess Ascl1 coexpression with other TFs involved in OPC differentiation, we performed immunofluorescence for different TF combinations and for markers of different stages of oligodendroglial lineage, including Gpr17, which is expressed during OPC differentiation (Chen et al., 2009; Boda et al., 2011). At P14, when many oligodendroglial cells are at different stages of differentiation in the CC, Ascl1 is coexpressed with Sox9, Sox10, Olig2, Olig1, and Nkx2.2 in PDGFR $\alpha^{+}$cells (OPCs; labeled \#1 in Fig. $2 C, D, J, K)$. According to the expression levels of these TFs and oligodendroglial markers, we could divide premyelinating oligodendrocytes in two stages (Fig. $2 C-K$ ): (1) premyelinating oligodendrocyte stage I ( $\mathrm{mOLI}$ ) characterized by downregulation of Ascl1, Olig1, and PDGFR $\alpha$ and upregulation of Nkx2.2/Gpr17/ APC/Sox9/Sox10 (labeled \#2 in Fig. 2C-K); and (2) premyelinating oligodendrocyte stage II (pre-mOLII), implicating the downregulation of $\mathrm{Nkx} 2.2 / \mathrm{Gpr} 17$ and upregulation of Olig1cytoplasmic expression while presenting the highest levels of Sox9/Sox10/Olig2 (labeled \#3 in Fig. $2 C-K$ ). Ascl1 ${ }^{G F P}$ transgene was still expressed at these premyelinating stages characterized by coexpression of high levels of Nkx2.2/Olig2 or Sox10/Olig2, indicating that Ascl1-expressing OPCs do differentiate into maturing oligodendrocytes (Fig. $2 I, K$ ). Eventually, APC cells starting to express myelin proteins, such as MOG, present a larger cytoplasm and intermediate levels of Olig2/Sox9/Sox10 expression with persistent Olig1 cytoplasmic expression (labeled \#4 in Fig. $2 \mathrm{H}, J, \mathrm{~K})$. Therefore, combinatorial expression of Ascll and other oligodendrogenic factors defines more precisely the successive stages of oligodendrogenesis. The initial stage of OPC differenti- 

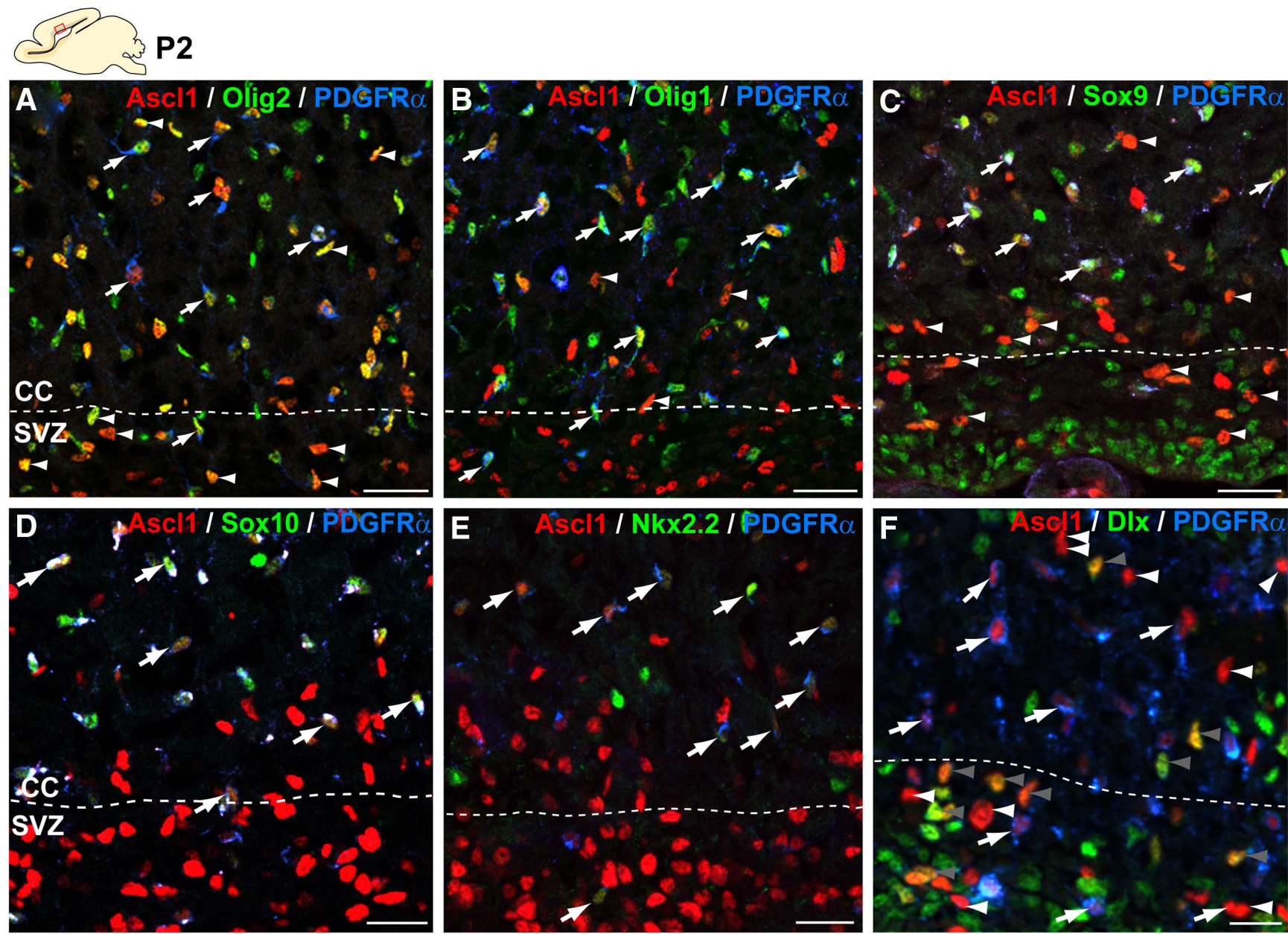

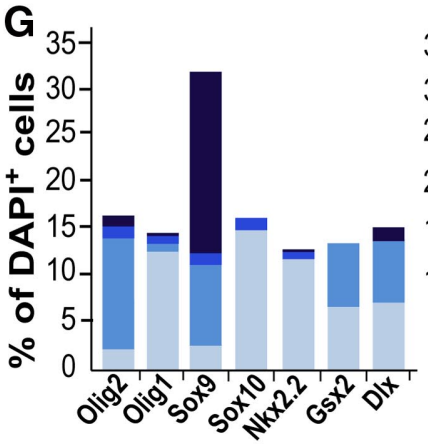

SVZ

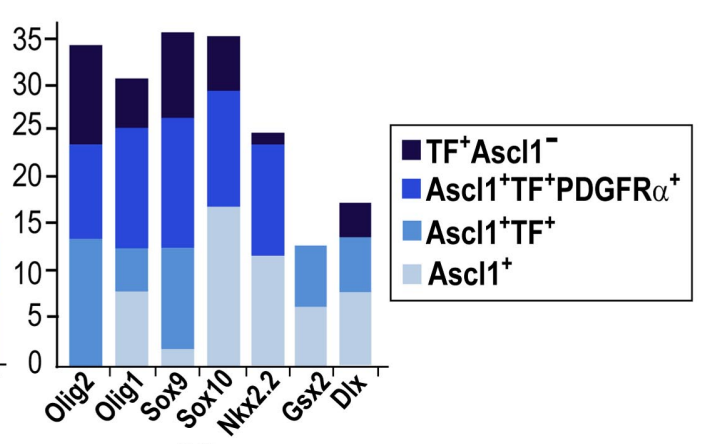

CC
H

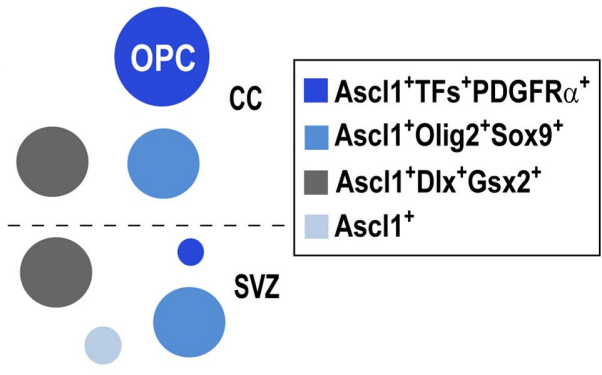

Figure 1. Neonatal subsets of Ascl1-expressing cells in SVZ and CC include neuronal or oligodendroglial progenitors and OPCS. A-E, Sections through the dorsal SVZ and CC of P2 wild-type neonates showing by immunofluorescence the expression of Ascl1 protein together with 0lig2, Sox9, Sox10, and Nkx2.2 in PDGFR $\alpha^{+}$cells (OPCs, arrows) or PDGFR $\alpha^{-}$cells (arrowheads). $A_{\text {, AsCl1 }}$ is coexpressed with Olig2 in immature progenitors (PDGFR $\alpha^{-}$cells) and OPCs both in SVZ and CC, whereas Ascl1 is coexpressed with Olig1 in PDGFR $\alpha^{+}$OPCs and few PDGFR $\alpha^{-}$cells of the CC (B). C, Ascl1 is coexpressed with Sox9 in all PDGFR $\alpha^{+}$OPCs and most Ascl1 ${ }^{+} /$PDGFR $\alpha^{-}$cells, $30 \%$ of SVZ cells being Sox $9^{+}$. Ascl1 is coexpressed with Sox 10 (D) and Nkx2.2 (E) in all PDGFR $\alpha^{+}$OPCs but not in PDGFR $\alpha^{-}$cells. F, Pan-Dlx antibody (recognizing Dlx1/2/5/6 proteins) labels half of Ascl1 ${ }^{+} /$PDGFR $\alpha^{-}$cells (gray arrowheads compared with white arrowheads) but not OPCs (arrows). G, Histograms representing the percentage of cells (DAPI ${ }^{+}$) in the SVZ and CC that express Ascl1 together with other TFs, using PDGFR $\alpha$ to label OPCs. Ascl1 ${ }^{+}$represents Ascl1-only-expressing cells (light gray), Ascl1 ${ }^{+} \mathrm{TF}^{+}$are PDGFR $\alpha^{-} / \mathrm{Ascl}^{+}{ }^{+}$cells coexpressing the other TF (light blue), $\mathrm{TF}^{+}{ }^{-} \mathrm{Ascl} 1^{-}$are TF-only-expressing cells (dark blue). $\boldsymbol{H}$, Summary figure representing in circles the Ascl1 ${ }^{+}$populations both in SVZ and CC. In the SVZ, $10 \%$ of Ascl1 ${ }^{+}, \mathrm{PDGFR} \alpha^{-}$cells are Ascl1-only-expressing cells (light gray), whereas $90 \%$ are 0 lig2 $2^{+} / \mathrm{Sox} 9^{+}$, and these can be subdivided in two halves by their expression of Dlx/Gsx2 (gray) or not (light blue). These two last populations are also present in the forming CC, where half of Ascl1 ${ }^{+}$cells are OPCs (expressing PDGFR $\alpha$, 0lig2, Olig1, Sox9, Sox10, and Nkx2.2). Dlx and Gsx2 are not expressed in OPCS, and most likely Ascl $1^{+} / 0$ lig2 ${ }^{+} / \mathrm{S}_{0 \times} 9^{+} / \mathrm{Gsx2} 2^{-} / \mathrm{Dlx}{ }^{-}$cells are oligodendroglial progenitors. Dotted line represents the border between SVZ and CC. Scale bars, $20 \mu \mathrm{m}$.

ation is marked by a transient upregulation of $\mathrm{Nkx} 2.2 / \mathrm{Gpr} 17$ correlating with a downregulation of Ascl1/Olig1 (Fig. 2J,K), whereas further steps of transition toward a myelin-forming cell correlate with $\mathrm{Nkx} 2.2 / \mathrm{Gpr} 17$ downregulation together with Olig1 cytoplasmic expression (Fig. $2 \mathrm{~J}, \mathrm{~K}$ ).
Ascl1 is required for OPC generation from SVZ progenitor cells

Given the expression of Ascl1 in SVZ-progenitors and in OPCs during the postnatal wave of oligodendrogenesis described above, we first investigated its role in cortical SVZ progenitors 

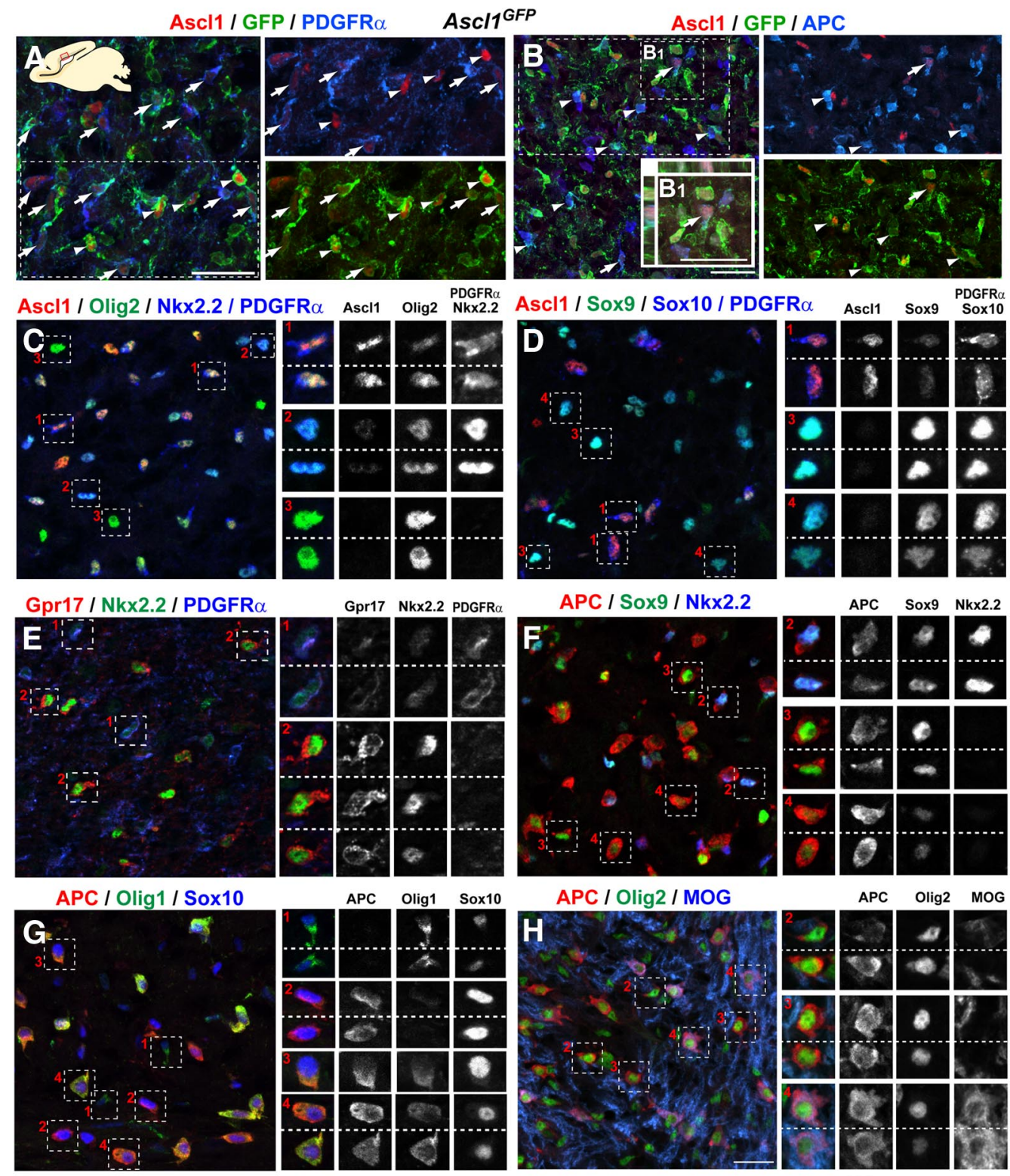

APC / Olig2 / MOG

APC Olig2 MOG
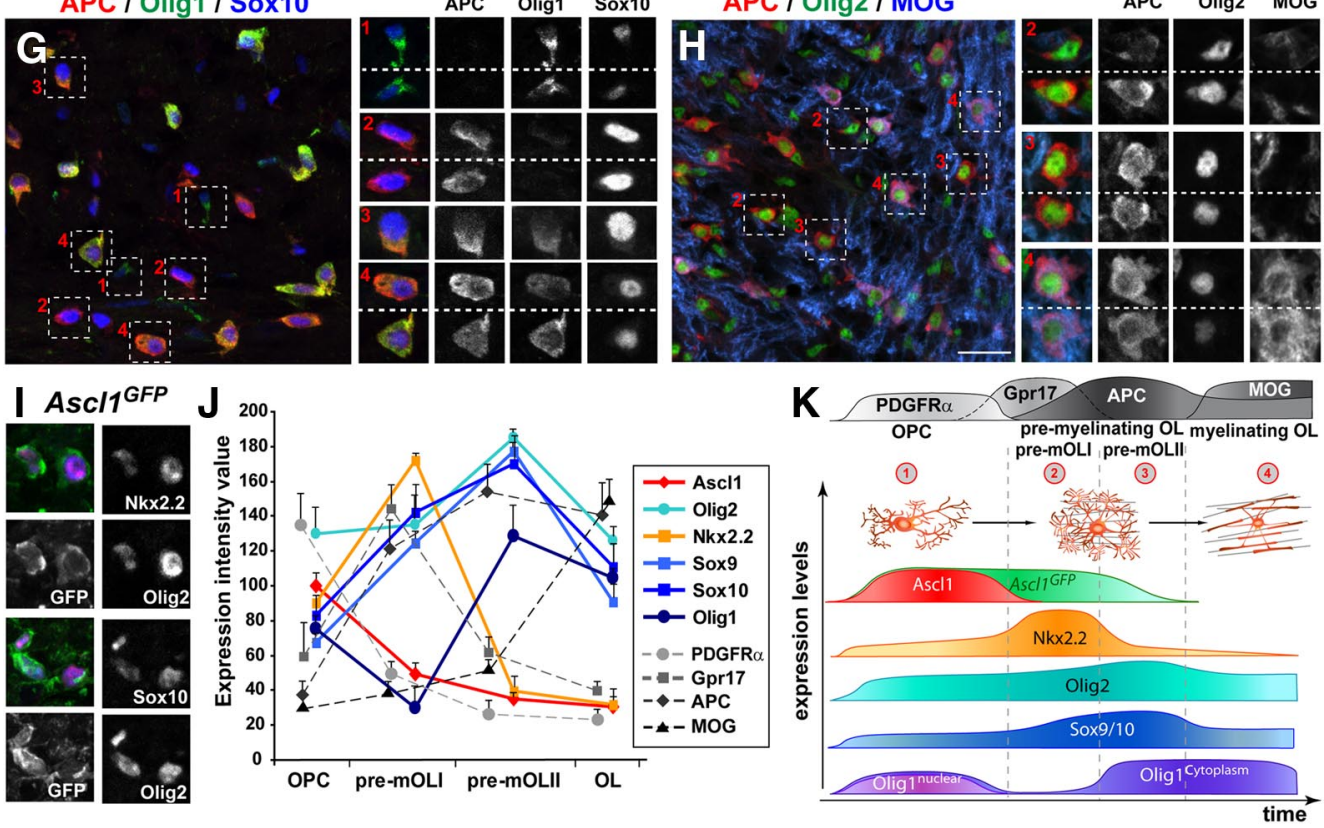

Figure 2. Expression pattern of Ascl1 and other TFs involved in oligodendrogenesis progression in the postnatal brain. $A-I$, Sections of P7 $(\boldsymbol{A}, \boldsymbol{B})$ or P14 (C-I) CC immunolabeled with antibodies against Ascl1, GFP, and main TFs involved in oligodendrogenesis. $\boldsymbol{A}, \boldsymbol{B}$, Sections of $A s c 11^{\text {GFP }}$ P7 brain showing Ascl1 and GFP expression in all PDGFR $\alpha^{+}$OPCs (A, arrows) and some PDGFR $\alpha^{-}$cells $\left(\boldsymbol{A}\right.$, arrowheads), whereas APC ${ }^{+}$oligodendrocytes express only GFP ( $\boldsymbol{B}$, arrowheads) and very rarely Ascl1 protein $\left(\boldsymbol{B}_{\boldsymbol{1}}\right.$, arrow). $\boldsymbol{C}-\boldsymbol{H}$, Sections of P14 wild-type brains showing that: Ascl1 is coexpressed in PDGFR $\alpha^{+}$cells (OPCS, stage 1) together with Olig2 and Nkx2.2 (C) or Sox9 and Sox10 (D,E) but not in maturing oligodendrocytes that express high levels of 0lig2, Nkx2.2, Sox9, and Sox10 (C-E).E, $\boldsymbol{F}$, Nkx2.2 is expressed at high levels in cells being Gpr17 ${ }^{+} / \mathrm{PDGFR} \alpha^{-} / \mathrm{APC}^{+}$and high levels of 0lig2, Sox9 $\left(\boldsymbol{C}, \boldsymbol{E}, \boldsymbol{F}\right.$, named stage 2, pre-0LI). $\boldsymbol{G}, 0$ lig1 is not expressed in some APC ${ }^{+}$ cells with high levels of Sox10 expression (stage 2, pre-0LI cells), but it is highly expressed in the cytoplasm of other APC ${ }^{+}$cells with high or intermediate levels of Sox 10/Sox9/0lig2 and low levels of Nkx2.2 (C-F; stage 3, pre-0LII). $\mathbf{H}, \mathrm{APC}^{+}$cells expressing high levels of 0lig2 (stages 2 and 3 ) are $\mathrm{MOG}^{-}$, corresponding to premyelinating oligodendrocytes, whereas APC ${ }^{+}$cells expressing intermediate levels of Olig2 correspond to MOG ${ }^{+}$myelinating oligodendrocytes (stage 4). I, Ascl1 ${ }^{G F P}$ transgene is expressed in cells with high levels NkX2.2, Olig2, and Sox10, suggesting that Asc11-expressing cells give rise to maturing oligodendrocytes. $J$, Line chart representing the relative fluorescence intensity of each TF (color lines) and oligodendroglial markers (gray dotted lines) in stage of oligodendrogenesis. $\boldsymbol{K}$, Summary scheme (based on values in $\boldsymbol{J}$ ) for Ascl1 and other TFs expression profile during different stages of (Figure legend continues.) 
and neonatal oligodendrogenesis. For this purpose, we deleted Ascl1 in dorsal SVZ cells in a temporally controlled manner by targeting a Cre-expressing plasmid to the dorsal SVZ at P2 of $\mathrm{Ascll}^{f l / \Delta}$; Rosa26 $6^{\text {stop-YFP }}$ (mutant, Cko ${ }^{d S V Z}$ ) or $\mathrm{Ascll}^{f l /+}$; Rosa $26^{\text {stop-YFP }}$ (control, Ctr ${ }^{d S V Z}$ ) mice, using a modified postnatal electroporation technique (Boutin et al., 2008). In control experiments using a GFP-expressing plasmid, many GFP ${ }^{+}$SVZ cells showed radial glial-like processes, thus demonstrating that dorsal neural progenitor/stem cells were successfully targeted by our electroporation technique (Fig. $3 B$ ). In brains electroporated with Cre-expressing plasmids, Ascl1 protein was detected only in $C t^{d S V Z}$ but not in $C k o^{d S V Z}$ cells (Fig. $3 C, C_{1}, C^{\prime}, C^{\prime}{ }_{1}$ ), indicating that Ascll could be efficiently deleted by Cre recombination. To assess the fate of electroporated cells, we analyzed the brains at $30 \mathrm{~d}$ postelectroporation (dpe). The majority of $\mathrm{Ctr}^{d S V Z}-\mathrm{YFP}^{+}$ cells were oligodendrocytes $\left(62.5 \pm 5.6 \%, n=5\right.$, APC $\left.{ }^{\text {high }}\right)$, some were astrocytes $\left(32.1 \pm 5.9 \%, n=5, \mathrm{GFAP}^{+} / \mathrm{APC}^{\text {low }}\right)$, and few were OPCs $\left(9.3 \pm 0.8 \%, n=3, \mathrm{PDGFR} \alpha^{+}\right)$(Fig. $\left.3 D, D_{1}, E\right)$. In contrast, $C k o^{d S V Z}-\mathrm{YFP}^{+}$cells were mostly astrocytes $(82.9 \pm$ $4.1 \%, 2.7$-fold), only $15.3 \pm 1.8 \%$ were oligodendrocytes (3.9fold reduction), and $1.6 \pm 0.5 \%$ were OPCs (5.5-fold reduction) (Fig. $3 D^{\prime}, D^{\prime}{ }_{1}, E$ ), indicating that loss of Ascl1 inhibits oligodendrogenesis for the benefit of astrogenesis. We did not observe a selective cell death of Ascl1-deficient cells at 3 dpe (as shown by the absence of activated caspase 3 expression; data not shown). There was also a 1.7-fold increase in the number of Ascl1deficient $\mathrm{GFAP}^{+}$cells in the SVZ compared with controls $(88.9 \pm 11.1 \%$ vs $48.3 \pm 4.7 \% ; p=0.0082$, $t$ test, $n=4$; Fig. $\left.3 D, D_{1}\right)$. Ascl1 is therefore required for the proper generation of oligodendrocytes from the cortical SVZ; and, in the absence of Ascl1, the SVZ progenitor's fate is predominantly astroglial.

\section{Ascl1 promotes the balance between OPC differentiation and proliferation}

We next examined Ascll function specifically in neonatal OPCs by performing a temporal and conditional Ascl1 deletion in OPCs of $C k o^{O P C}$ and $C t r^{O P C}$ genotypes using PDGFR $\alpha: \mathrm{CreER}^{T 2}$ mice (Rivers et al., 2008; see Materials and Methods). We induced Ascl1 deletion at early postnatal stages when OPC numbers peak in the brain (tamoxifen injection at P5 or P8-P9) and assessed their proliferative and differentiation capacity. Ki67 expression in OPCs was used as marker of proliferative OPCs. Seven days posttamoxifen injection (dpi) $\mathrm{CkO}^{\mathrm{OPC}} \mathrm{YFP}^{+}$OPCs showed a 1.7-fold increase in the proportion of $\mathrm{Ki}^{+}$cells $(36.4 \pm 5.2 \%$, Fig. $\left.4 A^{\prime}, D\right)$ compared with $C_{t r}{ }^{O P C}(21.3 \pm 0.7 \%$, Fig. $4 A, D)$, indicating an increase of OPC proliferation in the absence of Ascll. Similar results were obtained when tamoxifen was injected at P5 or P8-P9 (Fig. 4D). Therefore, OPC proliferation increases in the absence of Ascl1.

Neonatal OPCs have been shown to divide either symmetrically, generating pairs of OPCs (OPC/OPC pairs) or mature oligodendrocytes ( $\mathrm{APC}^{+}$cells, named OL/OL pairs), or asymmetrically to generate one OPC and one oligodendrocyte (OPC/OL pairs) (Sugiarto et al., 2011; Zhu et al., 2011). To assess whether the difference in proliferation rate observed in the ab-

$\leftarrow$

(Figure legend continued.) oligodendrogenesis. Stage 1 OPCs are PDGFR $\alpha^{+}$cells. Premyelinating (APC ${ }^{+}$cells) oligodendrocytes are divided in two stages: stage 2 (pre-0LI) are cells with high levels of Nkx2.2, Olig2, Sox9/10, and Gpr17 and negative for Olig1; stage 3 (pre-0LII) are cells with high levels of Olig2, Sox9/10, and cytoplasmic Olig1 and negative for NkX2.2/Gpr17. Stage 4 (myelinating oligodendrocytes) are $\mathrm{APC}^{+} / \mathrm{MOG}^{+}$cells. OL, Oligodendrocyte. Dotted squares represent areas shown at higher magnification. Scale bars, $20 \mu \mathrm{m}$. sence of Ascl1 could result from a change in OPC mode of division, we quantified the different types of $\mathrm{YFP}^{+}$cell pairs in the $\mathrm{CC}$ at $7 \mathrm{dpi}$. Ctr $^{\mathrm{OPC}}$ (tamoxifen at P5) showed $23.1 \pm 4.0 \%$ of OPC/OPC pairs, $29.0 \pm 3.5 \%$ of OPC/OL pairs, and $47.8 \pm 3.7 \%$ of OL/OL pairs (Fig. $4 A, A_{1}, A_{2}, F$ ). In $C k o^{O P C}$, we observed a twofold increase in OPC/OPC pairs $\left(48.4 \pm 2.7 \%\right.$; Fig. $\left.4 A^{\prime}, A^{\prime}{ }_{1}, F\right)$, a twofold decrease in OPC/OL pairs $(14.6 \pm 3.1 \%)$, and no change in numbers of OL/OL pairs $\left(37.0 \pm 5.9 \%\right.$; Fig. $\left.4 A^{\prime}, A^{\prime}{ }_{2}, F\right)$, suggesting that, in the absence of Ascl1, OPCs that would divide asymmetrically (OPC/OL pairs) divide instead symmetrically to generate two OPCs (Fig. $4 F$ ). Similar results were obtained when tamoxifen was injected at P5 or P8-P9 (Fig. 4F). Ascl1 thus regulates and promotes asymmetric divisions of OPCs. Consequently, the ratio of OPC/oligodendrocytes within the $\mathrm{YFP}^{+}$ population was increased in $C \mathrm{Ko}^{\mathrm{OPC}}$ cells (1.4-fold) compared with $\mathrm{Ctr}^{\mathrm{OPC}}$ cells $\left(\mathrm{Cko}^{\mathrm{OPC}}: 57.1 \pm 1.5 \% \mathrm{APC}^{+}\right.$cells vs $42.8 \pm$ $1.5 \%$ PDGFR $\alpha^{+}$cells; $n=5 ;$ Ctr $^{O P C}: 47.6 \pm 1.8 \% \mathrm{APC}^{+}$cells vs $52.4 \pm 1.5 \% \operatorname{PDGFR} \alpha^{+}$cells; $n=3$, Fig. $4 E$ ), indicating that loss of Ascl1 in OPCs favors proliferation over differentiation. The differentiation defect of Ascl1-mutant cells appeared more pronounced regarding their expression of myelin proteins, such as CNP (Fig. $4 C-C^{\prime}{ }_{2}, E$ ). To assess whether these differences were maintained at later stages, we studied the proportion of OPCs and oligodendrocytes present at $28 \mathrm{dpi}$. A similar ratio of 4:1 oligodendrocytes per OPC was found in $\mathrm{Cko}^{\mathrm{OPC}}$ and $\mathrm{Ctr}^{\mathrm{OPC}}$ cells $\left(\mathrm{Cko}^{\mathrm{OPC}}: 79.6 \pm 0.9 \% \mathrm{APC}^{+}\right.$cells vs $20.4 \pm 0.8 \% \mathrm{PDGFR} \alpha^{+}$ cells, $n=5$; Ctr $^{O P C}: 79.8 \pm 1.8 \% \mathrm{APC}^{+}$cells vs $20.1 \pm 1.8 \%$ PDGFR $\alpha^{+}$cells, $n=4$; Fig. $\left.4 B, B^{\prime}, G\right)$, suggesting that other factors regulating OPC proliferation and differentiation compensate for the loss of Ascll function over time.

\section{Demyelination upregulates Ascl1 levels in adult OPCs}

Because Ascl1 expression is lost with oligodendrocyte differentiation, we then extended our study to adulthood to determine whether Ascll was still expressed in OPCs under normal and demyelinating conditions. Using an optimized protocol for Ascl1 immunofluorescence (see Materials and Methods), we detected intermediate to low levels of Ascl1 in young (P70) and aged (P200) brain, in virtually all OPCs (99\%) in the CC, whereas high levels were observed in the neurogenic regions (i.e., SVZ/rostral migratory stream [RMS]; Fig. $5 A, B, G)$. Ascll expression was also detected at low levels in a large majority of OPCs $(>90 \%)$ in other brain regions, including in the gray matter (in the hippocampus, thalamus, olfactory bulb; Fig. $5 C$; and data not shown) and the white matter (in the fimbria, striatum, cerebellum, brainstem; data not shown). In the cortex, Ascl1 expression was detectable in a large fraction (67\%) of OPCs (Fig. 5D). These results are in accordance with the expression of the GFP reporter in $A s c l 1^{G F P}$ mice in the adult brain (Fig. 5B) (Parras et al., 2007).

In the adult CNS, demyelination results in the upregulation of several TF involved in oligodendrogenesis, including upregulation of Olig2, Nkx2.2, and Sox10 transcripts (Fancy et al., 2004, 2009; Watanabe et al., 2004). To determine whether Ascl1 expression is also altered in response to demyelination, we used adult Ascl1 ${ }^{\text {GFP }}$ animals to perform LPC-induced focal demyelinating lesions in the CC, as previously reported (Nait-Oumesmar et al., 1999). At 5 d postlesion (dpl), cells expressing high to intermediate levels of Ascl1 and Ascl1 ${ }^{G F P}$ (Ascl $1^{\text {high }} / A s c l 1^{G F P+}$ cells) were detected both in the SVZ and within and around the lesion, which was characterized by a very dense cellularity (Fig. $5 E-E_{2}$ ).

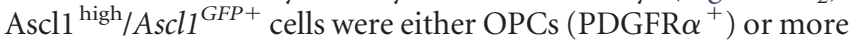
immature precursors (PDGFR $\alpha^{-}$cells), the latter having (as shown by GFP expression) characteristics of migrating cells (Fig. 

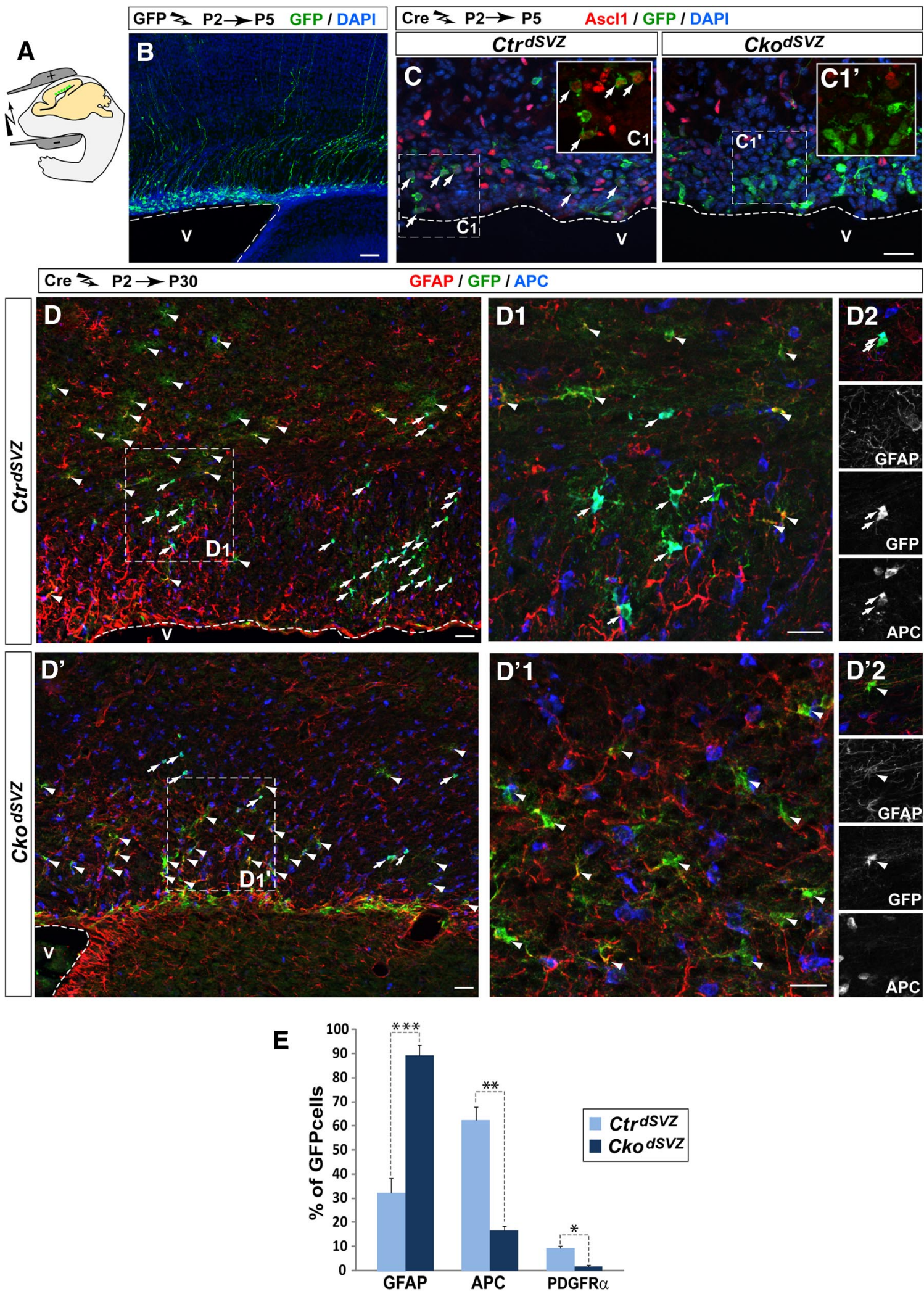

Figure 3. Ascl1 conditional ablation in dorsal SVZ cells reduces postnatal oligodendrogenesis. $A$, Schematic representation of the dorsal SVZ electroporation in P2 neonates. Green dots represent dorsal SVZ electroporated cells. B, Sagittal section of GFP-electroporated wild-type brain at $3 \mathrm{dpl}$, showing GFP incorporation in dorsal precursors, including some containing radial glial processes.

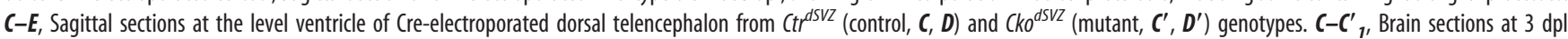
immunostained for Ascl1 and YFP showing that Ascl1 is present in some YFP ${ }^{+}-$Ctr ${ }^{d S V Z}$ cells (arrows) but not in YFP ${ }^{+}-C k 0^{d S V Z}$ cells; Ascl1 is still present in YFP ${ }^{-}$-nonelectroporated cells. $\mathbf{D}, \boldsymbol{D}^{\prime}$, Brain sections at $28 \mathrm{dpl}$ immunostained for GFAP (red), YFP (green), and APC (blue). APC ${ }^{+}$oligodendrocytes (arrows) are strongly reduced in YFP ${ }^{+}$-Ckod ${ }^{d S V Z}$ cells, most being GFAP ${ }^{+}$cells (arrowheads). $D_{1}, D_{1}{ }^{\prime}$, Higher magnifications of insets in $\boldsymbol{D}_{1} \boldsymbol{D}^{\prime} . \boldsymbol{D}_{2}, \boldsymbol{D}_{2}{ }^{\prime}$, Examples of YFP ${ }^{+}$cells coexpressing APC or GFAP cells in either genotype. $\boldsymbol{E}$, Histograms representing the percentage of YFP ${ }^{+}$cells in the

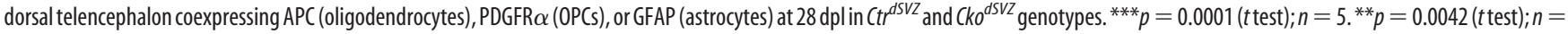
5. ${ }^{*} p=0.035$ ( $t$ test $) ; n=3$. Scale bars, $20 \mu \mathrm{m}$. 


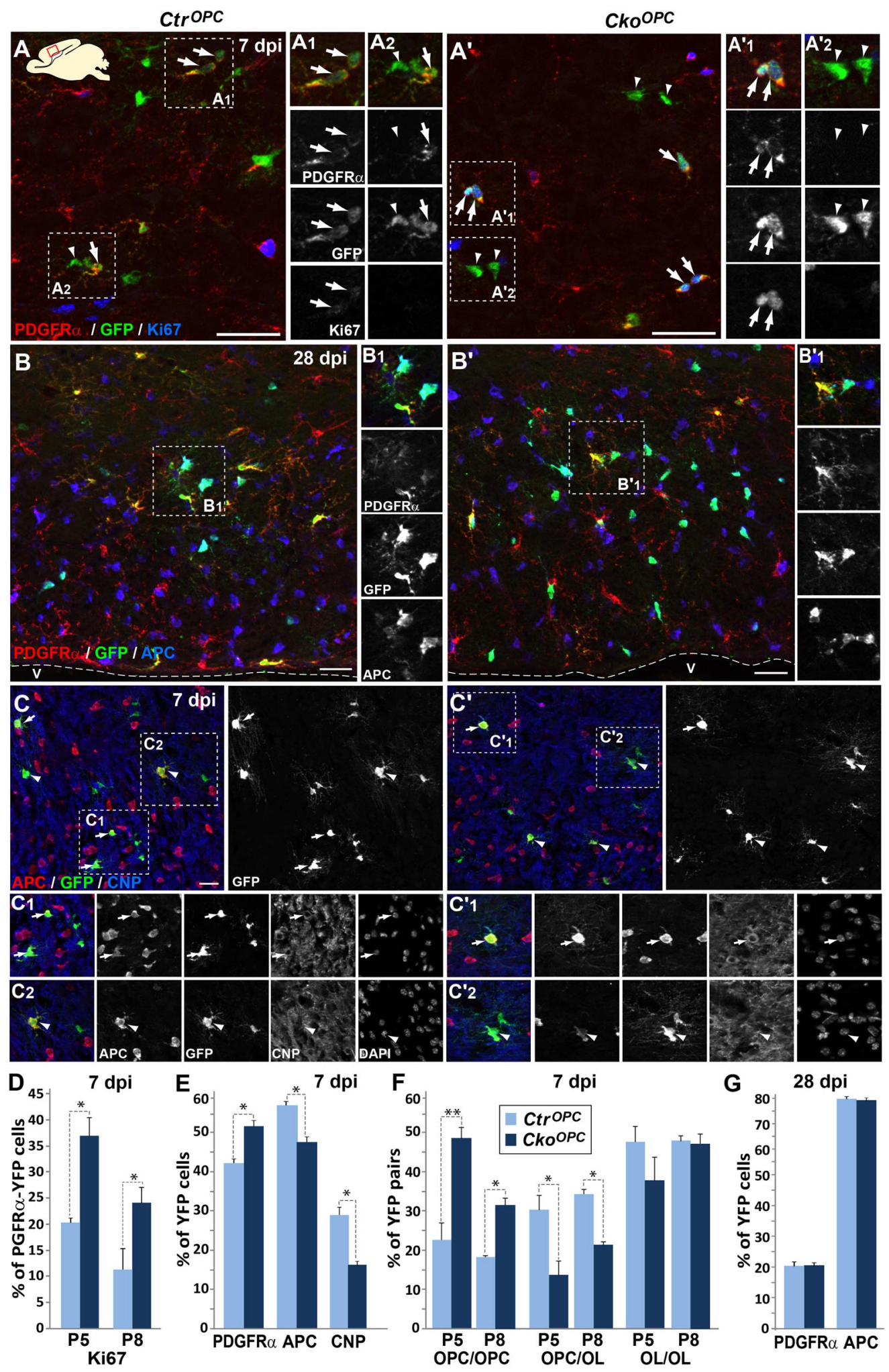

Figure 4. Ascl1 controls postnatal OPC division, proliferation, and differentiation. $A-C^{\prime}$, Sagittal sections through the $C\left(\right.$ of $C t r^{O P C}($ control, $A-C)$ or $C k 0^{O P C}$ (mutant, $\left.\boldsymbol{A}^{\prime}, \boldsymbol{B}^{\prime}, \boldsymbol{C}^{\prime}\right)$ brains at $\mathrm{P} 12(\boldsymbol{A}$, $\left.\boldsymbol{A}^{\prime}, \boldsymbol{C}_{,} \boldsymbol{C}^{\prime}\right)$ or P33 $\left(\boldsymbol{B}, \boldsymbol{B}^{\prime}\right)$ immunolabeled with antibodies against YFP and markers of oligodendroglial cells. $\boldsymbol{A}, \boldsymbol{A}^{\prime}$, Tamoxifen-injected brains analyzed at 7 dpi (P12) immunolabeled for cell cycle marker Ki67 illustrating the increase of proliferating YFP ${ }^{+} \mathrm{OPCs}\left(\right.$ Ki67 ${ }^{+} / \mathrm{YFP}^{+} / \mathrm{PDGFR} \alpha^{+}$cells) in Ascl1 mutant cells $\left(\boldsymbol{A}^{\prime}, \boldsymbol{A}^{\prime}{ }_{\boldsymbol{1}}\right)$ compared with controls $\left(\boldsymbol{A}, \boldsymbol{A}_{\boldsymbol{\eta}}\right)$. YFP ${ }^{+}$cells are often found as pairs of either two PDGFR $\alpha^{+}$cells $\left(\boldsymbol{A}_{1}, \boldsymbol{A}^{\prime}{ }_{1}\right)$, or either one $\left(\boldsymbol{A}_{2}\right)$ or two YFP ${ }^{+} /$PDGFR $\alpha^{-}$cells (differentiating oligodendrocytes, $\left.\boldsymbol{A}^{\prime}{ }_{2}\right)$, and in Cko ${ }^{\text {OPC }}$ pairs of two PDGFR $\alpha^{+}$cells are increased and pairs

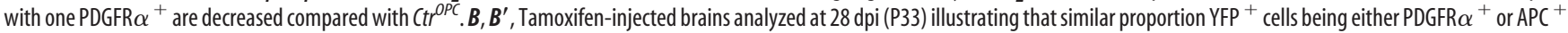
cells in $\mathrm{Ctr}^{O P C}(\boldsymbol{B})$ and $C \mathrm{Ko}^{O P C}\left(\boldsymbol{B}^{\prime}\right) . \boldsymbol{C}, \boldsymbol{C}^{\prime}$, Brain sections analyzed at 7 dpi immunolabeled for $\mathrm{CNP}$ myelin protein, APC, and YFP showing that less YFP ${ }^{+}-\mathrm{Cko}^{O P C}$ cells $\left(\boldsymbol{C}^{\prime}\right)$ are APC ${ }^{+} / \mathrm{CNP}^{+}$(arrows) compared with $\mathrm{Ctr}^{O P C}$ cells $(\boldsymbol{C})$ as illustrated at higher magnification in $\boldsymbol{C}_{\mathbf{1}}-\mathbf{C}_{2}{ }_{2} \cdot \mathbf{D}-\mathbf{G}$, Histograms representing the quantification of the data illustrated in previous panels showing the following: (D) an increase in proliferation (Ki67 ${ }^{+}$) of mutant PDGFR $\alpha^{+}$OPCs at 7 pdi injected either at P5 $\left({ }^{*} p=0.016, t\right.$ test, $\left.n=3\right)$ or P8 $\left({ }^{*} p=0.039, t\right.$ test, $\left.n=3\right) ;(\boldsymbol{E})$ an increase in OPCs $\left({ }^{*} p=0.038, t\right.$ test, $n=3$ ) and a corresponding decrease of $\mathrm{APC}^{+}\left({ }^{*} p=0.041, t\right.$ test, $\left.n=3\right)$ or $\mathrm{CNP}^{+} / \mathrm{APC}^{+}$oligodendrocytes $\left({ }^{*} p=0.030, t\right.$ test, $\left.n=3\right)$ in Cko ${ }^{\text {OPC }}$ cells compared with (Figure legend continues.) 
$5 E_{1}$ ). Ascl1 expression in OPCs (relative to its expression in SVZ cells) was upregulated to levels similar postnatal OPCs (Fig. 5G). Moreover, Ascl1 ${ }^{G F P+}$ cells in the lesion (Fig. $5 F$ ) and in the SVZ (data not shown) coexpressed high levels of Olig2 and Nkx2.2, suggesting that all three TFs are upregulated in progenitors and nearby OPCs involved in remyelination.

Ascl1 expression was not induced in oligodendrocytes upon/ after demyelination given that Ascll protein was not detected in Olig2 ${ }^{+} / \mathrm{APC}^{+}$cells (Fig. $5 \mathrm{H}$, arrowheads). However, the GFP transgene was expressed in maturing oligodendrocytes of Ascl1 ${ }^{G F P}$ animals (cells expressing high levels of Olig2 and Sox10, Fig. 5I, $I_{1}$ ), as we previously observed at postnatal stages (Fig. 2). These data indicate that, in both the postnatal brain and in response to demyelination, a similar combination of TFs, including Ascll is induced in OPCs/progenitors and likely involved in (re)myelination.

\section{Ascl1-expressing cells repopulate demyelinated lesions}

$\mathrm{Ascl}^{+}$progenitor/OPCs are localized in and around focal LPC lesions, suggesting that they may differentiate locally into myelinating oligodendrocytes and participate to myelin repair. In Ascl1 ${ }^{G F P}$ mice, GFP expression persists long after that Ascll is downregulated, which allows cell fate mapping of Ascll progeny. We have examined the contribution of Ascll-expressing cells to oligodendrocyte regeneration and lesion repair in $A s c l 1^{G F P}$ mice. The demyelinated lesion can be recognized by a dense cellularity, the absence of myelin proteins (such as MBP; Fig. 6A), and oligodendrocyte depletion $\left(\mathrm{APC}^{+}\right.$cells, Fig. $\left.6 C, E\right)$. At $2 \mathrm{dpl}$, there were many $\mathrm{GFP}^{+}$cells in the lesion, most of them being OPCs (79\%; PDGFR $\alpha^{+} / \mathrm{Olig}^{+}$cells, Fig. $6 \mathrm{D}$ ) and the remaining cells being immature progenitors. At $5 \mathrm{dpl}$, the number of $\mathrm{GFP}^{+}$cells in the lesion was increased sevenfold, $\sim 60 \%$ being OPCs (Fig. $6 \mathrm{~B}, \mathrm{D})$. At both time points, all OPCs were $\mathrm{GFP}^{+}$, indicating that OPCs present within the lesion derive from Ascll-expressing cells. In addition, at $5 \mathrm{dpl}, 25 \%$ of $\mathrm{GFP}^{+}$cells in the lesion were $\mathrm{APC}^{+}$oligodendrocytes (Fig. $6 C, E$ ), suggesting that these cells had differentiated locally from Ascl $1^{+}$OPCs/progenitors.

OPCs contributing to myelin lesion repair in the CC may derive from progenitors located in the SVZ (Nait-Oumesmar et al., 1999, 2008; Aguirre et al., 2007; Franklin and ffrenchConstant, 2008; Staugaitis and Trapp, 2009). LPC-induced Ascl1 ${ }^{G F P}$ mice showed OPCs associated with $\mathrm{GFP}^{+} / \mathrm{PDGFR} \alpha^{-}$ progenitors in the RMS, displaying a bipolar shape morphology and with the main cell body axis oriented toward the CC where the lesion is located (Fig. $6 F, F_{1}$ ). This observation suggests that Ascl $1^{+}$progenitors and OPCs generated in the SVZ/RMS neurogenic zone can migrate away from the RMS toward CC lesions, likely recruited with signals delivered from the injured tissue.

\section{Ascl1 progenitors differentiate into remyelinating oligodendrocytes}

To assess the contribution of Ascl ${ }^{+}$progenitors to the remyelination process, we used the Cre/loxP recombination system to trace the Ascl1-cell lineage in LPC-demyelinated mice. LPCinduced lesions were performed in the CC of adult Ascl1 ${ }^{\text {Cre/YFP }}$

$\leftarrow$

(Figure legend continued.) $\mathrm{Ctr}^{\mathrm{OPC}}$ at $7 \mathrm{dpi} ;(\boldsymbol{F})$ an increase in PDGFR $\alpha^{+}$pairs (OPC/OPC) and a decrease of PDGFR $\alpha^{+}-\mathrm{APC}^{+}$pairs (OPC/OL), with no change in $A P C+{ }^{+}$pairs $(0 \mathrm{~L} / \mathrm{OL})$ in $C \mathrm{KO}^{O P C}$ cells at 7 dpi injected with tamoxifen at $P 5\left({ }^{* *} p=0.0073\right.$ and ${ }^{*} p=0.032$, respectively, $t$ test, $n=3)$ or at P8 $\left({ }^{*} p=0.041\right.$ and ${ }^{*} p=0.019$, respectively, $t$ test, $\left.n=3\right)$; and (G) no difference in the YFP ${ }^{+}$cells being either PDGFR $\alpha^{+}$or APC ${ }^{+}$cells between $\mathrm{Ctr}^{\mathrm{OPC}}$ and $\mathrm{CkO}^{\mathrm{OPC}}$ cells at later stages (28 dpi). OL, Oligodendrocyte; $V$, ventricle. Scale bars, $20 \mu \mathrm{m}$. mice, and the presence of intralesional $\mathrm{APC}^{+} / \mathrm{YFP}^{+}$oligodendrocytes was investigated at 5, 14, and $28 \mathrm{dpl}$. At all stages examined, the majority $(67 \%)$ of intralesional PDGFR $\alpha^{+}$OPCs and $\mathrm{APC}^{+}$oligodendrocytes expressed YFP and belong to the Ascl1 cell lineage (Fig. $7 A, D$ ), with a similar proportion of YFP ${ }^{+}$oligodendrocytes present in nonlesion territories (Fig. 7D). At 14 $\mathrm{dpl}$, intralesional $\mathrm{APC}^{+} / \mathrm{YFP}^{+}$cells expressed myelin proteins, such as MOG (Fig. $7 B, C, C_{1}, C_{2}$ ), suggesting that these cells were maturing into myelinating oligodendrocytes. We also used EM to identify intralesional $\beta$-galactosidase ${ }^{+} / \mathrm{X}$-gal ${ }^{+}$myelinating oligodendrocytes using $\mathrm{Ascl1}{ }^{\mathrm{Cre} / \mathrm{LacZ}}$ mice. X-gal-reaction deposits were detected within the lesion area, in cells with ultrastructural characteristics of newly formed oligodendrocytes enwrapping multiple axons (Fig. $7 E, E_{1}, E_{2}$ ). These observations confirmed that $\mathrm{Ascl}^{+}$progenitors/OPCs generate myelin-forming cells that participate in myelin repair.

\section{Ascl1 is required for normal timing of OPC differentiation during remyelination}

To determine Ascl1 requirement for proper remyelination, we deleted Ascl 1 expression specifically in OPCs before inducing CC myelin lesion. We assessed whether $\mathrm{YFP}^{+}{ }_{-} \mathrm{CkO}{ }^{\mathrm{OPC}}$ cells were able to migrate into lesions, proliferate, and differentiate in the absence of Ascll. At 8 and $15 \mathrm{dpl}$, remyelinating lesions in both $C k o^{O P C}$ and $C \operatorname{tr}^{O P C}$ displayed YFP ${ }^{+}$cells being PDGFR $\alpha^{+}$OPCs and $\mathrm{APC}^{+}$oligodendrocytes (Fig. $8 A, A^{\prime}, B, B^{\prime}$ ). This result indicates that Ascl 1 is dispensable for OPC recruitment and subsequent oligodendrocyte maturation in demyelinated lesions. At 8 dpi, the proportion of YFP ${ }^{+}$OPCs and $\mathrm{YFP}^{+}$oligodendrocytes was similar in $C k o^{O P C}$ and $C t r^{O P C}$. Nevertheless, a relatively large number of $\mathrm{YFP}^{+}-C k o^{O P C}$ cells were negative for either oligodendroglial (PDGFR $\alpha$ or APC) or astroglial (GFAP) markers at this stage (Fig. $8 B, B^{\prime}$ ). Some of them had typical oligodendrocyte morphology despite not expressing APC (Fig. $8 B^{\prime}$ ), most likely corresponding to cells with abnormal differentiation. In contrast at $15 \mathrm{dpl}, \mathrm{YFP}^{+}{ }_{-} C k o^{O P C}$ cells had a smaller ratio of oligodendrocyte to OPCs than $C t r^{O P C}$ cells (Fig. $8 C, C^{\prime}, E$ ), whereas the glial marker-negative population was very much reduced (Fig. 8). Moreover, we found fewer $\mathrm{YFP}^{+}$cells expressing CNP myelin protein in $C k o^{O P C}$ than in $C t{ }^{O P C}$ (Fig. $8 D, D^{\prime}, E$ ). Therefore, these data strongly suggest that Ascll is also required for normal OPC differentiation during remyelination and, as during myelination, other TFs most likely compensate its loss of function at later time points of the differentiation process.

\section{Ascl1 is expressed in active MS lesions}

In the mouse brain, Ascll expression is a hallmark of OPCs and precursor cells involved in remyelination. We hypothesized that, in humans, immature oligodendroglial cells in MS lesions may also express Ascll. To test this hypothesis, we examined Ascll expression in four MS and two non-neurological control postmortem brain samples. Lesions were first characterized using Luxol fast blue/cresyl violet (Fig. 9B), MOG, and CD68 immunolabeling (Fig. 9C). The expression of Ascl1 and of oligodendroglial markers (Olig1 and Sox10) was examined in actively remyelinating borders (patchy MOG staining $/ \mathrm{CD}^{+} 8^{+}$), in the chronic core of the lesions $\left(\mathrm{MOG}^{-} / \mathrm{CD}^{-} 8^{-}\right.$; Fig. $\left.9 \mathrm{C}\right)$, and in normal-appearing white matter (Fig. 9B,C). Ascl ${ }^{+}$cells were more numerous in active borders of MS lesions compared with chronic silent core or normal-appearing white matter. Moreover, the number of Ascl1 ${ }^{+}$cells was reduced in the core of chronic lesions compared with the other regions studied. Interestingly, $\mathrm{Ascl}^{+}$cells were more concentrated within the $\mathrm{CD} 68^{+}$active 

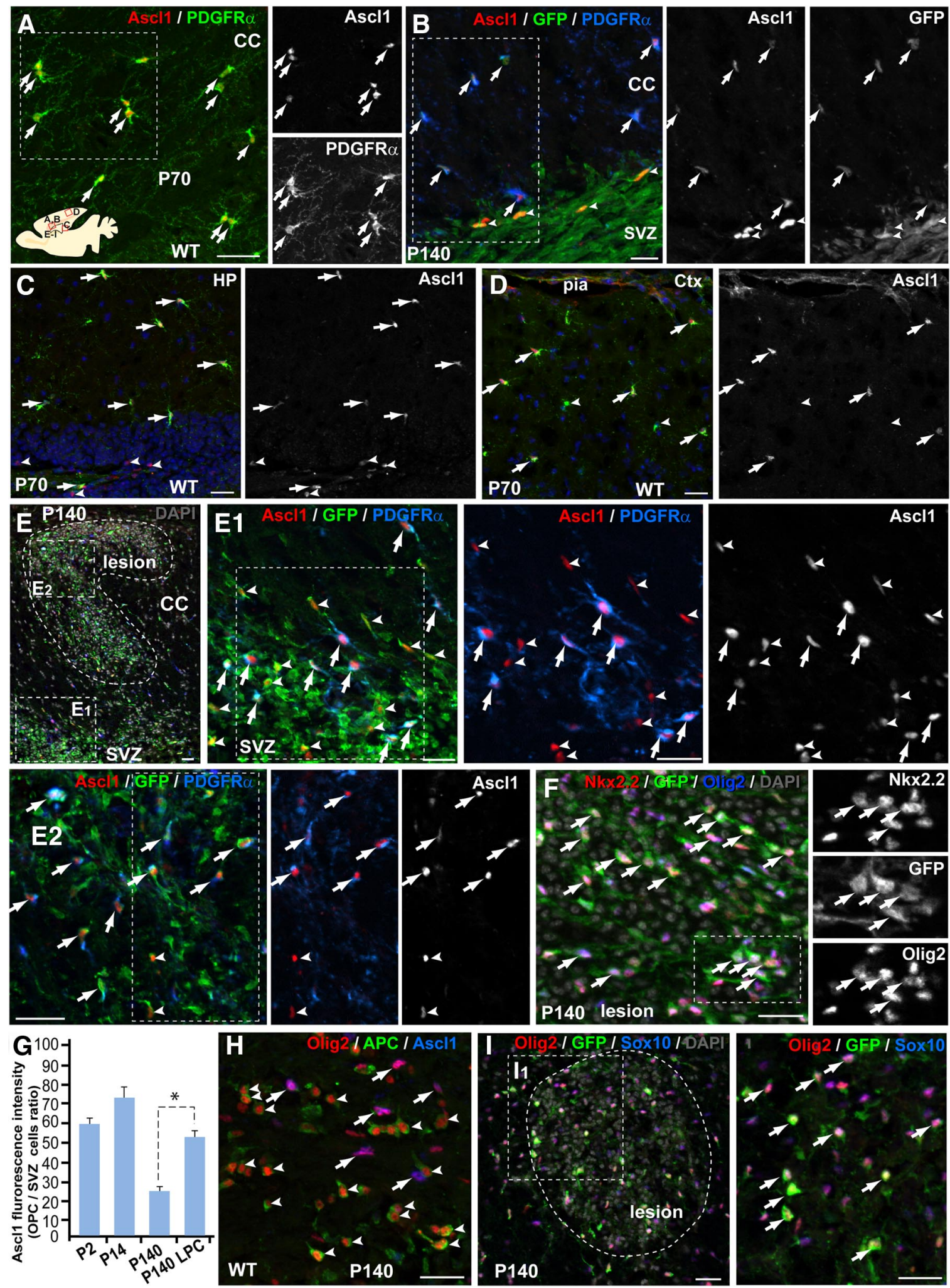

Figure 5. Ascl1-low expression in adult OPCs is upregulated upon demyelination. $A-D$, Sections of adult wild-type $(\boldsymbol{A}, \boldsymbol{C}, \boldsymbol{D}, \boldsymbol{H})$ or $A s c 17^{G F P}$ mice $(\boldsymbol{B}, \boldsymbol{E}, \boldsymbol{F}, \boldsymbol{I})$ in physiological conditions $(\boldsymbol{A}-\boldsymbol{D})$ or $5 \mathrm{~d}$ after focal demyelination of the $C($ ( $E-I) . A, C, D, P 70$ brain showing Ascl1 expression in all OPCs (PDGFR $\alpha^{+}$cells, arrows) in CC ( $\left.\boldsymbol{A}\right)$, HP ( $\boldsymbol{C}$, and many OPCs in the Ctx (D, Ascl1-negative OPCs indicated by arrowheads). $\boldsymbol{B}$, Ascl1 and Ascl1 ${ }^{\text {GFP }}$ transgene expression in SVZ cells (arrowheads) and OPCS (arrows) in the CC. The low levels of Ascl1 in OPCs are compared with SVZ cells. E, LPC lesion in the CC showing high levels of Ascl1 expression in PDGFR $\alpha^{+}$OPCs (arrows) comparable with SVZ cells (arrowheads) both near the SVZ $\left(\boldsymbol{E}_{1}\right)$ and the lesion ( $\boldsymbol{E}_{2}$, high cellularity, DAPI). $\boldsymbol{F}$, LPC lesion showing that cells coexpressing high levels of Olig2 and Nkx2.2 are Ascl1 ${ }^{G F P+}$. G, Histograms representing the relative expression levels of Ascl1 immunofluorescence in OPCs compared with SVZ cells at P2, P14, P140, and LPC lesion P140. There is an increase after LPC at levels present in postnatal OPCs. $\boldsymbol{H}, \boldsymbol{I}$, After LPC demyelination, Ascl1 protein is still restricted to OPCs and never found in Olig2 ${ }^{+} / \mathrm{APC}^{+}$oligodendrocytes (arrowheads), whereas Ascl $7^{G F P}$ transgene is expressed in cells with high levels of 0 lig2 and Sox 10 (differentiation oligodendrocytes, $I, I_{7}$ ). Dotted squares represent areas shown at higher magnification. HP, Hippocampus; Ctx, cortex. ${ }^{*} p=0.025(t$ test); $n=3$. Scale bars, $20 \mu \mathrm{m}$. 

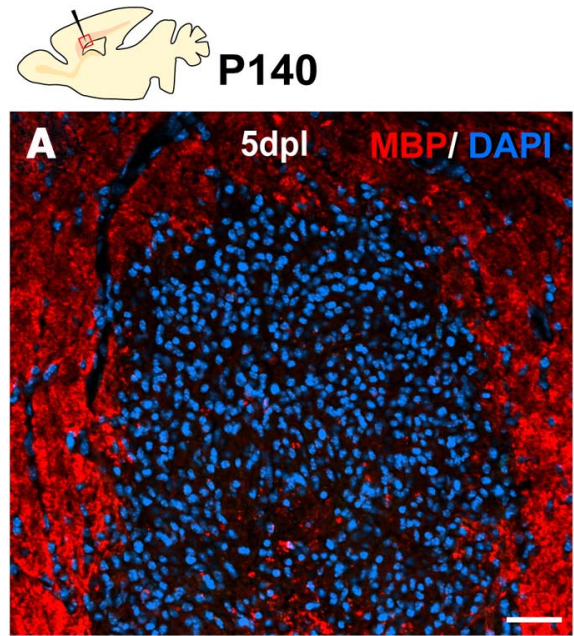

\section{Asc/1GFP}

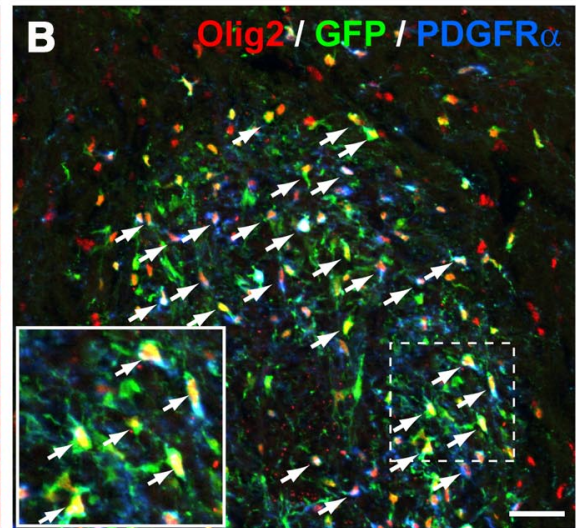

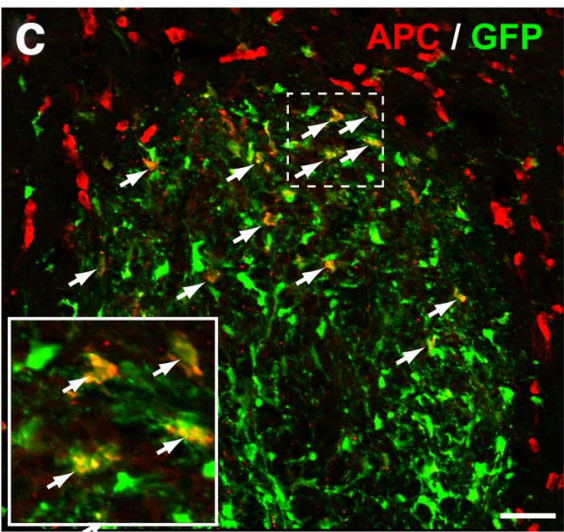
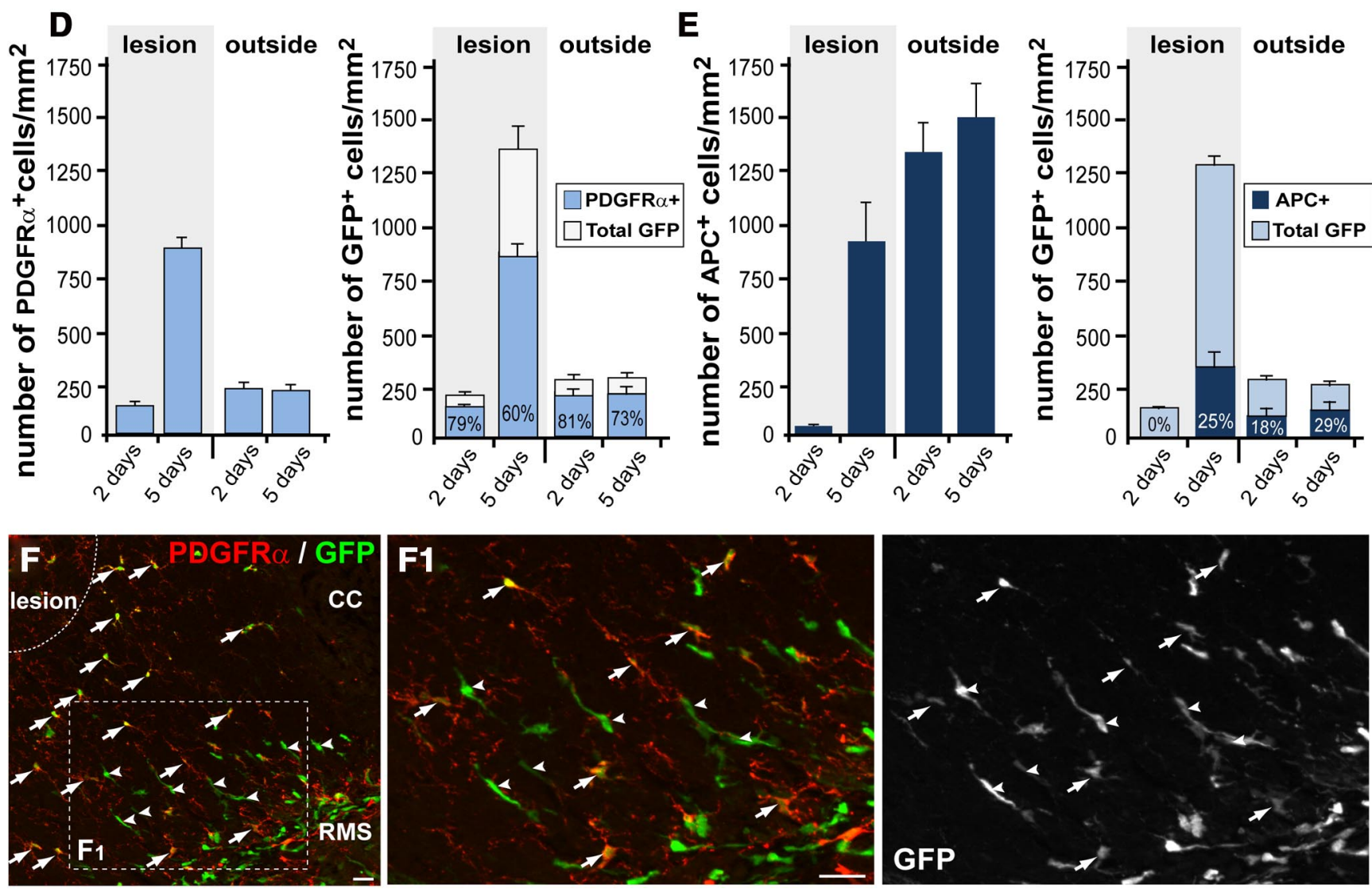

Figure 6. Ascl1-derived cells populated demyelinated lesions being mostly OPCs and maturing oligodendrocytes. Sections though the CC of adult (P140) Ascl1 ${ }^{G F P}$ brain $5 \mathrm{~d}$ after LPC lesion labeled by immunofluorescence. $\boldsymbol{A}$, Demyelinated lesion shown by loss of MBP staining and dense cellularity (DAPI). $\boldsymbol{B}$, Many GFP ${ }^{+}$cells are present in the lesion at $5 \mathrm{dpl}$ coexpressing 0 lig2 and PDGFR $\alpha$. C, Some GFP ${ }^{+}$cells in the lesion express APCs, suggesting that they are differentiating oligodendrocytes. $\boldsymbol{D}, \boldsymbol{E}$, Histograms showing quantification of PDGFR $\alpha^{+}(\boldsymbol{D})$ and $\mathrm{APC}{ }^{+}$cells $(\boldsymbol{E})$ inside the lesion (lesion, gray background) and in regions of CC far from the lesion (outside) at 2 and $5 \mathrm{~d}$ after the LPC lesion. White bars represent the total GFP ${ }^{+}$cells, a fraction of them expressing a given marker (blue). Almost all PDGFR $\alpha^{+}$cells in the lesion are GFP ${ }^{+}$, and $60 \%$ of the GFP ${ }^{+}$cells in the lesion are PDGFR $\alpha^{+}$and $25 \%$ express APCs. F, Ascl $17^{\text {GFP }}$ brain showing both OPCs (PDGFR $\alpha^{+} /$ $\mathrm{GFP}^{+}$cells, arrows) and GFP ${ }^{+}$-only cells (arrowheads) with main axis perpendicularly oriented to the RMS, suggesting their migration toward the demyelinated lesion in the CC. Scale bars, $20 \mu \mathrm{m}$.

borders of periventricular MS lesions (Fig. 9D) compared with other regions studied. Indeed, in other brain regions, including cortex and the normal-appearing white matter, Ascll expression level was very weak, most likely resulting from poor Ascll detection due to the fixation constraints of human brain samples. Nevertheless, the majority of Ascl1-expressing cells in active MS periventricular lesions were Olig1 ${ }^{+}$and Sox $10^{+}$(Fig. 9E,F), indicating that upregulation of Ascll in the endogenous OPCs may play a role in oligodendrocyte regeneration under pathological condi- tions. Overall, our findings on MS tissue are in agreement with our data on animal models of demyelination and demonstrate that Ascl1 is expressed at higher levels in oligodendroglial cells in MS plaques. Ascll may therefore be involved in oligodendrocyte differentiation and myelin repair in demyelinating pathology.

\section{Discussion}

In this paper, we show that Ascl1 is expressed during brain myelination and remyelination in SVZ progenitors and OPCs, play- 

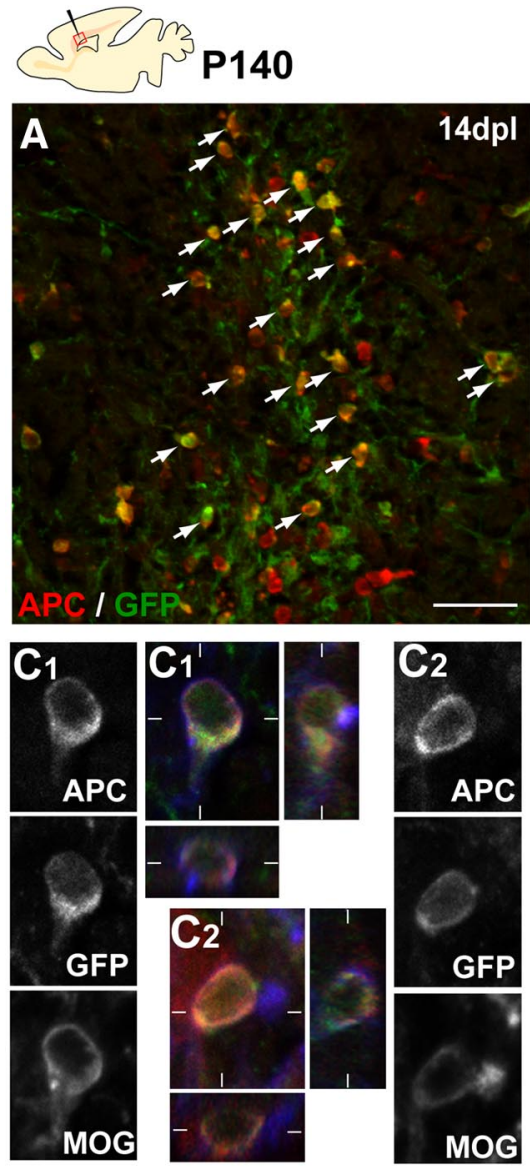

Ascl1Cre/YFP
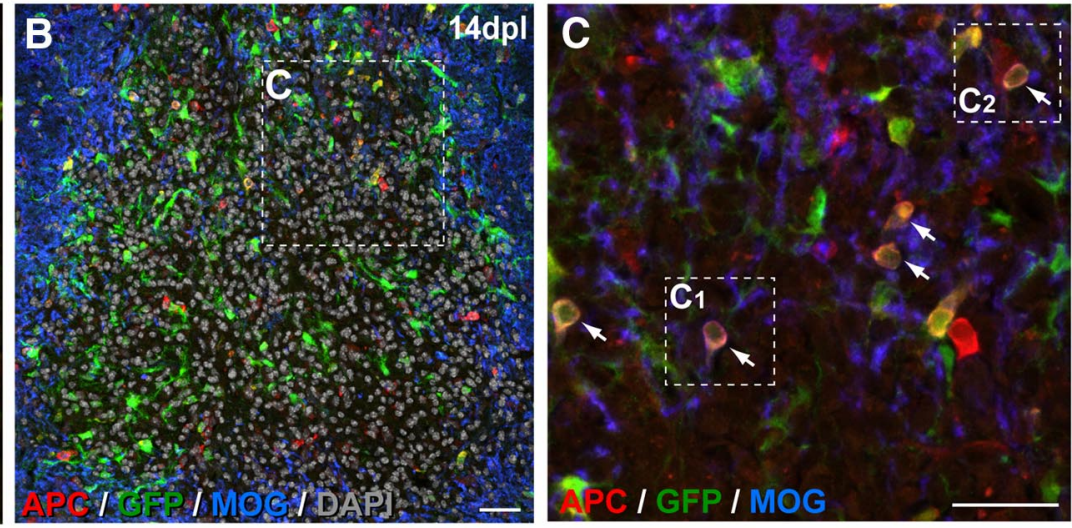

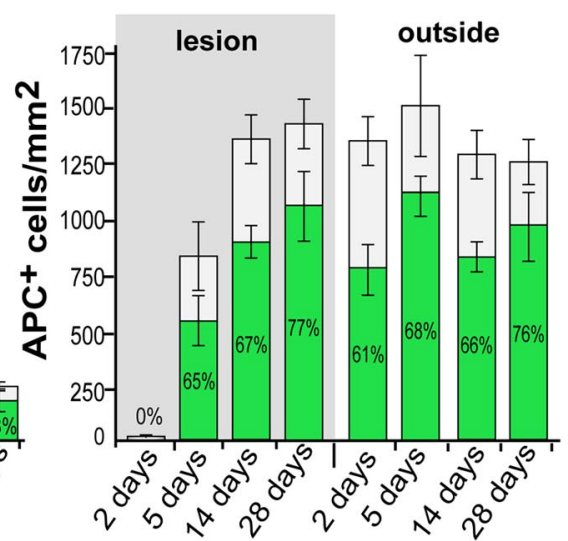

Ascl1Cre/LacZ
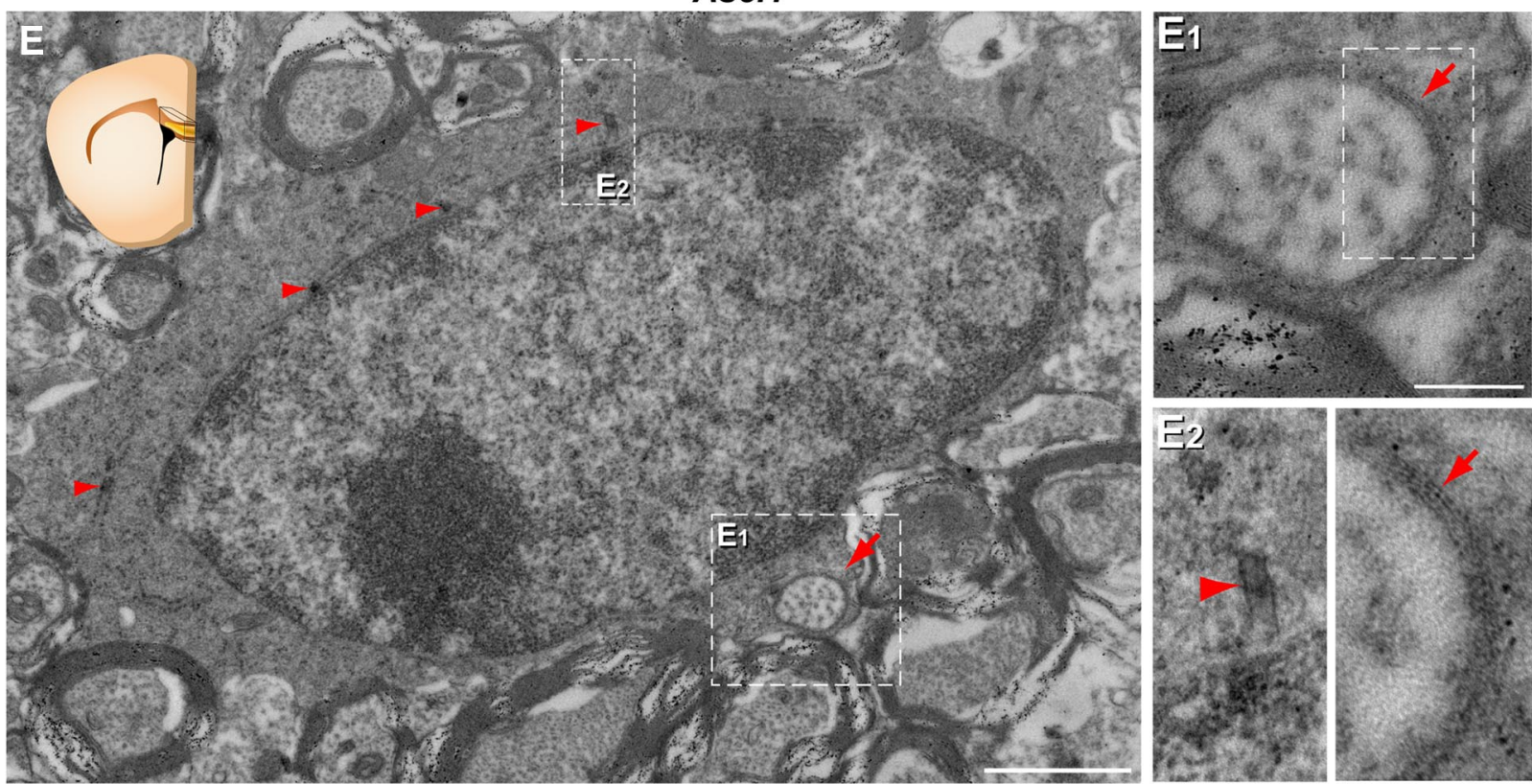

Figure 7. Ascl1 progenitor-derived cells generate remyelinating oligodendrocytes. $A-C$, Immunolabeling for YFP (green), APC (red), and MOG (blue) on coronal sections through the CC of an adult (P140) Asc17 ${ }^{\text {Cre/YFP }}$ mouse at day 14 after LPC lesion. $\boldsymbol{A}$, There is a high number of APC ${ }^{+} / \mathrm{YFP}^{+}$cells (arrows) (i.e., Ascl1 progenitor-derived cells) within the lesion. $\boldsymbol{B}$, Lower magnification of the demyelinated lesion characterized by the absence of MOG expression, high cellularity (DAPI, gray), and high number of YFP ${ }^{+}$cells. $\boldsymbol{C}$, High magnification of inset in $\boldsymbol{B}$ showing APC and MOG coexpression in a few YFP ${ }^{+}$cells (arrows). $\boldsymbol{C}_{1}, \boldsymbol{C}_{2}$, Individual channels and orthogonal projections of Z-stack pictures showing coexpression of MOG and APC in YFP ${ }^{+}$cells. $\boldsymbol{D}$, Histograms representing the number of PDGFR $\alpha^{+}$or APC ${ }^{+}$cells found in the lesion (lesion, gray background) or in regions of CC far from the lesion (outside) at different times after the lesion (2-28d). Green bars represent the relative number of $\mathrm{YFP}^{+}$cells among each of these populations. Oligodendrocytes $\left(\mathrm{APC}^{+}\right)$mainly belong to the Ascl 1 cell lineage. E, Electron micrograph images performed in a demyelinated zone of the $C C$, as shown in the schematic inset, from an Ascl1 ${ }^{\text {(re/LacZ }}$ mouse, at day 60 after lesion. X-gal reaction deposits (arrowheads) in the cytoplasm of a young oligodendrocyte (big cytoplasm) assessing that this cell belongs to the Ascl1 cell lineage $\left(\boldsymbol{E}_{,} \boldsymbol{E}_{2}\right) . \boldsymbol{E}_{1}$, High magnification of the inset in $\boldsymbol{E}$, showing a thin myelinated axon (remyelinated, arrow). Scale bars: $\boldsymbol{A}-\boldsymbol{C}, 20 \mu \mathrm{m} ; \boldsymbol{E}, 1 \mu \mathrm{m} ; \boldsymbol{E}_{1}$, $200 \mathrm{~nm}$. 

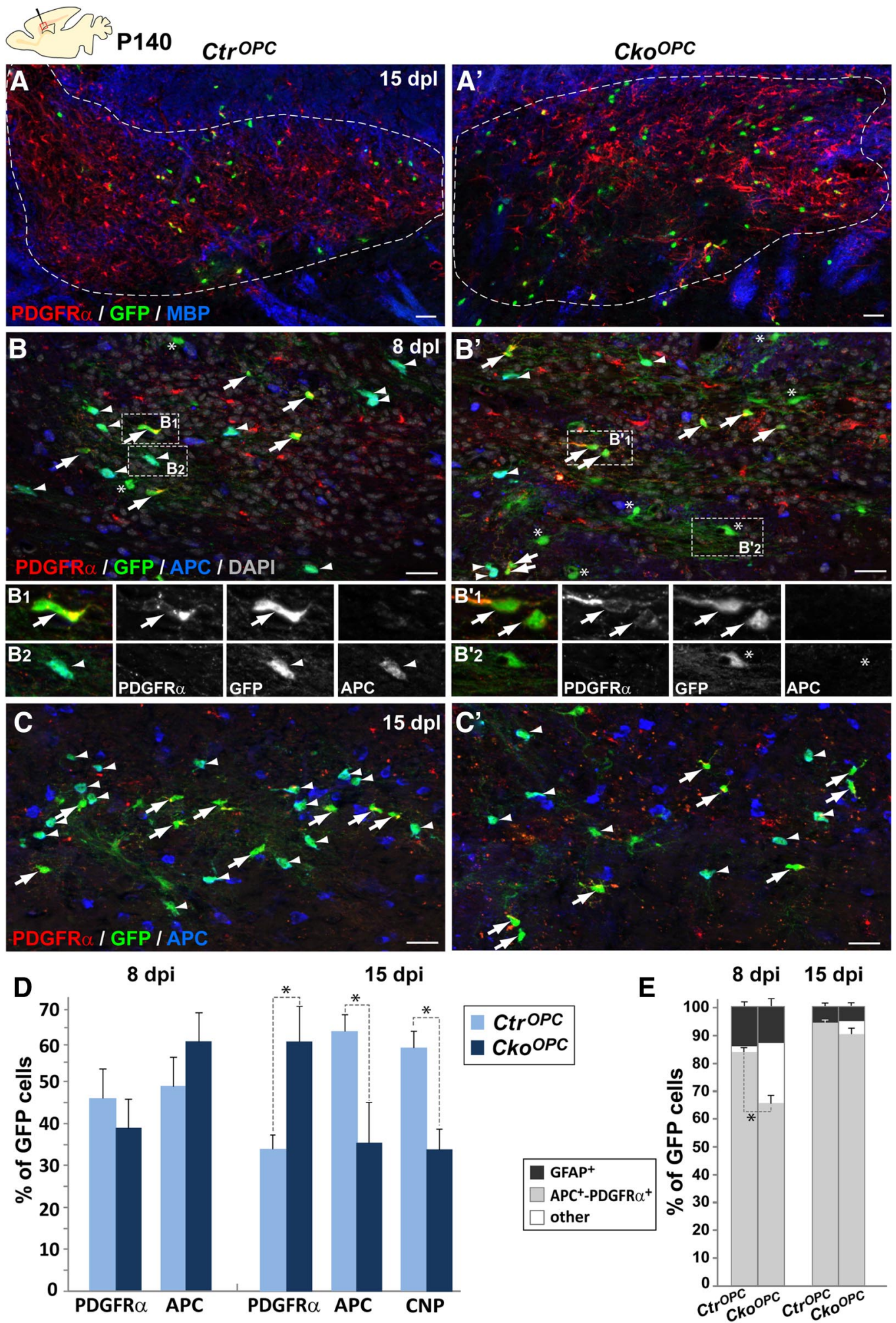

Figure 8. Ascl1 conditional deletion in adult OPCs reduces its differentiation during remyelination. $\boldsymbol{A}-\boldsymbol{D}^{\prime}$, Sagittal sections through the CC of adult (4 months), $C \mathrm{Cr}^{O P C}$ (Control, $\left.\boldsymbol{A}-\boldsymbol{D}\right)$ or $C \mathrm{C}^{O P C}$ (mutant, $\boldsymbol{A}^{\prime}-\boldsymbol{D}^{\prime}$ ) brains immunolabeled with antibodies against YFP and markers of oligodendroglial cells. $\boldsymbol{A}, \boldsymbol{A}^{\prime}$, , C lesion (dotted area) shown by the absence of MBP and high density of PDGFR $\alpha{ }^{+}$ cells, illustrating the presence of YFP ${ }^{+} /$PDGFR $\alpha^{+}$(arrows) and PDGFR $\alpha^{-}$(arrowheads) cells. $\boldsymbol{B}, \boldsymbol{B}^{\prime}$, Lesion area illustrating that there is a similar proportion of YFP ${ }^{+}$OPCs (arrows) that YFP ${ }^{+}$ oligodendrocytes (arrowheads) in $C \mathrm{KO}^{O P C}$ compared with $\mathrm{Ctr}^{O P C}$ at $8 \mathrm{dpl}$ but more YFP-marker-negative cells $\left(^{*}\right)$ in $C \mathrm{KO}^{O P C}$. $\boldsymbol{B}_{\boldsymbol{1}}, \boldsymbol{B}^{\prime}{ }_{2}$, Higher magnification of representative cells from each phenotype shown in separate color channels of the insets in $\boldsymbol{B}, \boldsymbol{B}^{\prime}$. There are oligodendrocyte morphology and lack of APC staining in $\boldsymbol{B}^{\prime}{ }_{2}$. $\boldsymbol{C}_{,} \boldsymbol{C}^{\prime}$, Lesion area illustrating that there is a bigger proportion of YFP ${ }^{+}$

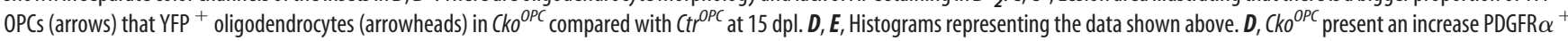
cells $\left({ }^{*} p=0.042, t\right.$ test, $\left.n=4\right)$ and decrease in APC ${ }^{+}\left({ }^{*} p=0.042, t\right.$ test, $\left.n=4\right)$ and CNP ${ }^{+}$cells $\left({ }^{*} p=0.038, t\right.$ test, $\left.n=4\right)$ at 15 dpi. $\boldsymbol{E}$, Histograms representing the fate of YFP ${ }^{+}$cells at 8 and $15 \mathrm{dpi}$ by the expression of oligodendroglial markers (PDGFR $\alpha^{+}$or APC ${ }^{+}$, gray bars), astroglial markers (GFAP ${ }^{+}$, black), or negative for these markers (others, white bars). There are more $\left(k 0^{\text {OPC }}\right.$ cells being neither oligodendroglial nor astroglial cells at $8 \mathrm{dpi}\left({ }^{*} p=0.021, t\right.$ test, $\left.n=3\right)$, whereas this population is much smaller at $15 \mathrm{dpi}$. Scale bars, $20 \mu \mathrm{m}$. 
A
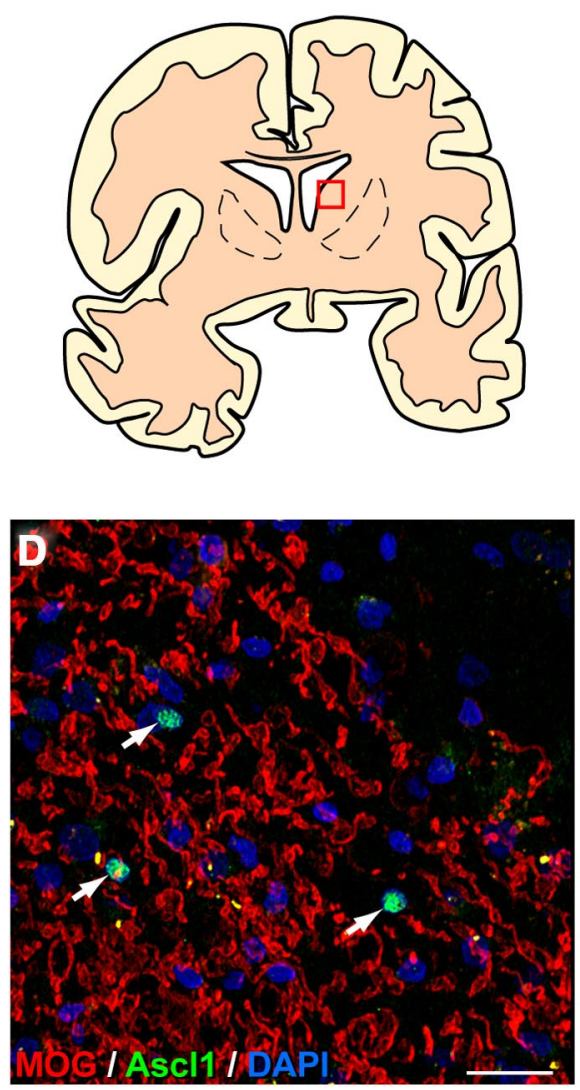
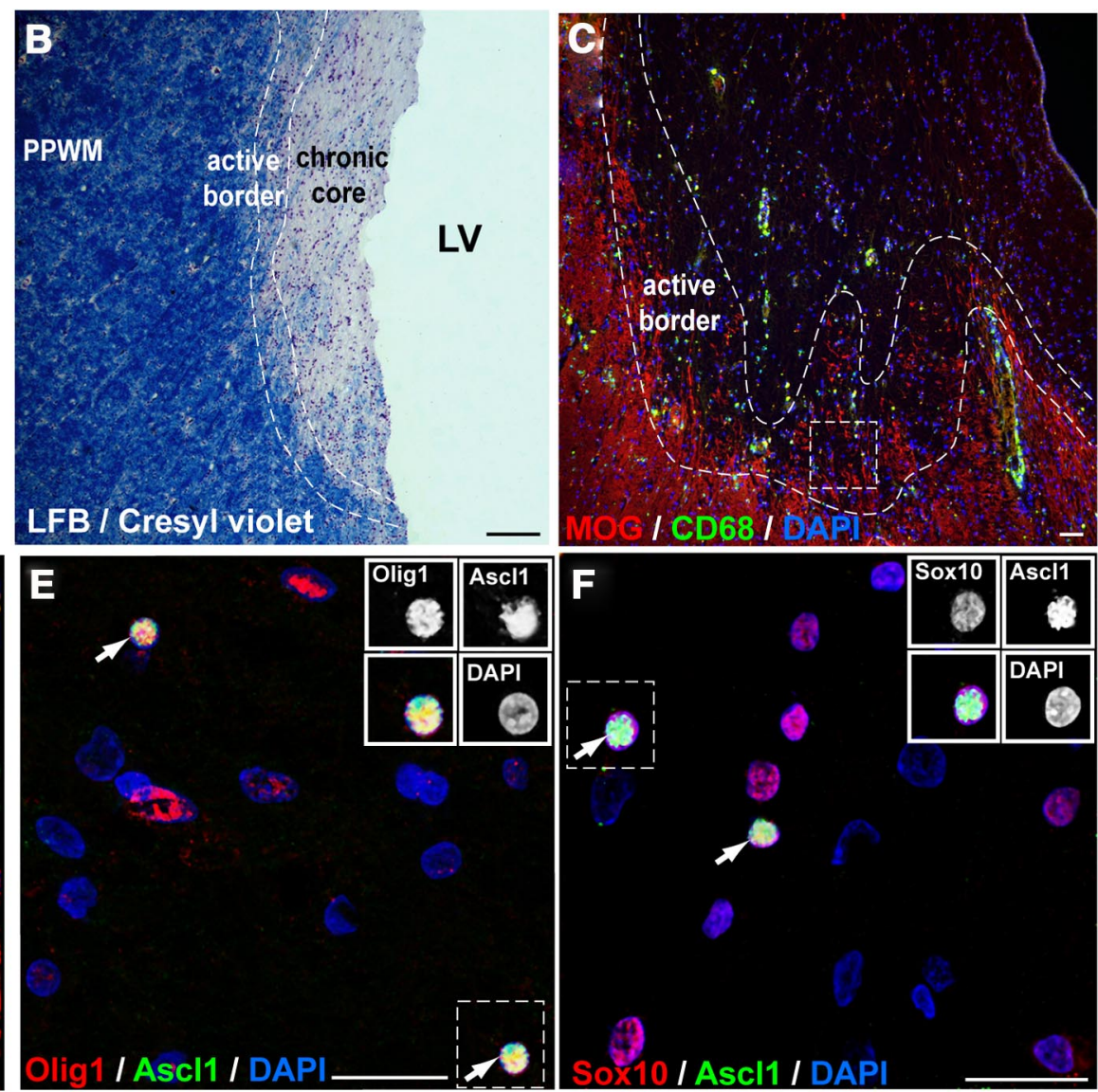

Figure 9. Ascl1 is expressed in oligodendroglial cells of active MS lesions. $\boldsymbol{A}$, Schematic representation of a human brain coronal section at the level of the lateral ventricle illustrating the localization (boxed area) of a periventricular MS lesion shown in $\boldsymbol{B}-\boldsymbol{F}$. $\boldsymbol{B}$, Luxol fast blue/cresyl violet staining reveals the typical feature of a chronic active periventricular lesion. $\boldsymbol{C}$, Lesion activity was confirmed by immunolabeling for MOG and CD68, and subdivided into active borders (CD68 ${ }^{+}$and MG ${ }^{+}$myelin debris) and chronic inactive core lacking $\mathrm{CD68}{ }^{+}$cells and M0G staining. $\boldsymbol{D}$, Immunodetection of Ascl1 ${ }^{+}$cells (arrows) in active regions. $\boldsymbol{E}, \boldsymbol{F}$, Double immunolabeling for Ascl1 and 0lig1 (arrow, $\boldsymbol{E}$ ) and Sox10 (arrow, $\boldsymbol{F}$ ) confirmed the oligodendroglial expression of Ascl1 in active MS lesions. Scale bars, $20 \mu \mathrm{m}$.

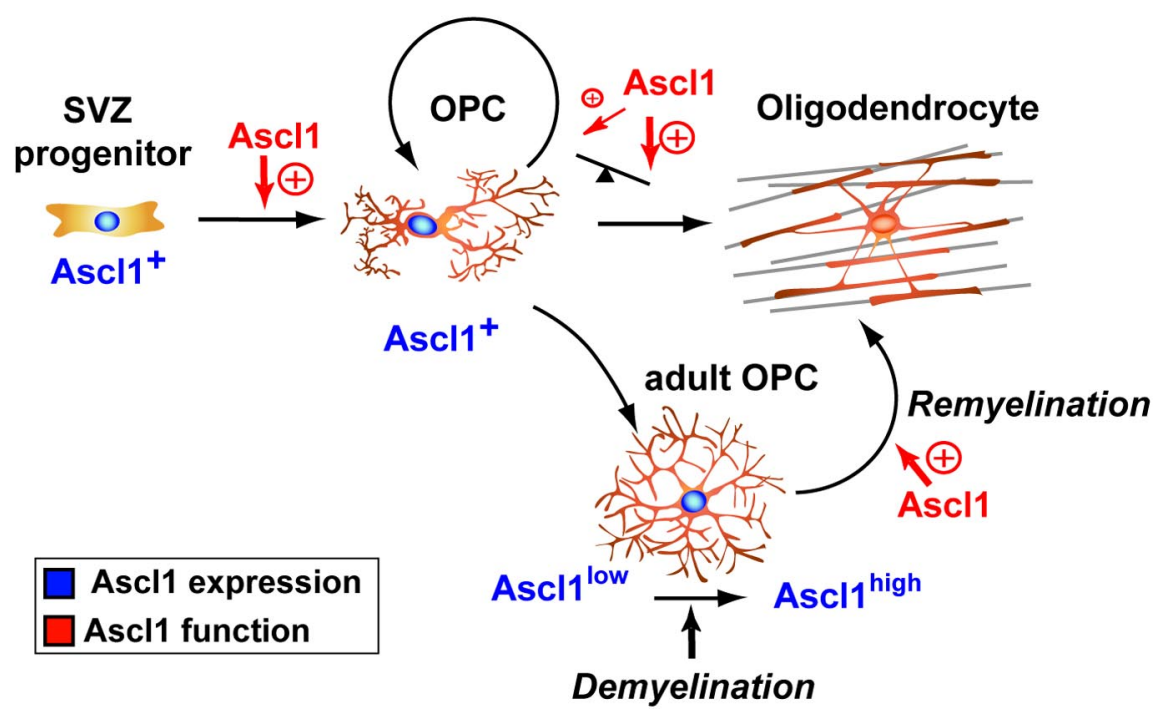

Figure 10. Working model for Ascl1 function in oligodendrogenesis. Ascl1 is expressed in cortical SVZ progenitors and the OPCS they generate, being downregulated upon oligodendrocyte differentiation. At postnatal stages, Ascl1 function is required in dorsal SVZ cells for normal OPC specification, and it is required in OPCs to balance OPC differentiation and proliferation. Ascl1 is maintained at low levels in adult OPCs, and its levels are upregulated upon demyelination being Ascl1 function required for normal OPC differentiation during remyelination. Arrow with plus symbol indicates functional requirement. Triangle with inclined line indicates Ascl1 function in the balance between OPC proliferation and differentiation, weighting more in the differentiation process. ing a cell-autonomous role both in OPC specification and in fine-tuning of OPC proliferation versus differentiation (Fig. 10). First, we demonstrate that Ascl1 is expressed in neonatal cortical SVZ progenitors and that its conditional deletion strongly suppress OPC generation, thus demonstrating that Ascll is required for postnatal oligodendrocyte specification. Second, Ascl1 is expressed in all OPCs in most brain regions and its conditional ablation in OPCs favors proliferative over differentiative OPC divisions, leading to a reduced number of oligodendrocytes. Third, Ascll is not expressed in differentiating oligodendrocytes, but lineagetracing studies show that Ascl1-expressing cells differentiate into myelinating and remyelinating oligodendrocytes. Fourth, Ascl1-expressing cells (OPCs and immature progenitors) are found in and around active lesions both in mouse and MS brain, Ascl1 being required for normal OPC differentiation during remyelination in mice and most likely implicated in human remyelination. 


\section{Ascl1 promotes OPC specification}

Ascl1-conditional deletion in dorsal SVZ cells strongly reduces the generation of oligodendroglial cells in the dorsal telencephalon and the majority of Ascl1-deficient cells become instead astrocytes. This effect could be the result of the following: (1) selective cell death of Ascl1-deficient oligodendroglial cells; (2) reduced proliferation of oligodendroglial cells in the absence of Ascl1; (3) blocking of Ascl1-deficient SVZ cells at immature progenitor stage; or (4) specification switch from oligodendrocyte to astrocyte fate in the absence of Ascl1. We did not find preferential cell death of Ascl1-deficient SVZ cells or of their progeny. Also, Ascl1-deficient OPCs proliferate more than controls. In contrast, we found a 1.7-fold increase in the number of Ascll-deficient $\mathrm{GFAP}^{+}$cells in the SVZ compared with controls. Therefore, Ascl1 is most likely required for OPC specification in the postnatal SVZ; and in the absence of Ascl1, the majority of SVZ cells become astrocytes or remain undifferentiated progenitors. In vivo clonal studies would be required to discriminate between these two possibilities. Indeed, a role in oligodendrocyte specification is supported by previous reports on in vitro experiments of Ascl1 loss- and gain-of-function in progenitors. Clonal neurosphere cultures of Ascl1-deficient progenitors display a reduced capacity to generate oligodendrocytes (and neurons) and differentiate instead into astrocytes (Parras et al., 2004), whereas Ascl1overexpressing progenitors favor oligodendrocyte differentiation at the expense of an astrocytic fate (Sugimori et al., 2007).

\section{Cell-autonomous Ascl1 function in oligodendrogenesis}

It has been suggested that Ascll plays an indirect role in oligodendrogenesis by Notch-mediated repression of the neurogenic determinants Dlx1/2 (Petryniak et al., 2007). However, in contrast with the embryonic expression of Ascl1 in a subset of OPCs (Parras et al., 2007; Sugimori et al., 2007), we demonstrate here that Ascl1 protein is present in the majority of postnatal brain OPCs, suggesting that Ascl1 plays a cell-autonomous function in oligodendrogenesis. Some immature progenitors coexpress Ascl1 and Dlx in oligodendrocyte-generating regions of embryonic (Petryniak et al., 2007) and postnatal telencephalon (current study), leaving space for Dlx inhibition of OPC specification. Nevertheless, Ascll conditional deletion in either SVZ cells or OPCs not only alters oligodendrocyte specification, but OPC proliferation versus differentiation balance, demonstrating a cellautonomous role of Ascll at different stages of oligodendrogenesis. It is worth noting that Ascll and Olig2 are coexpressed in immature SVZ, suggesting that OPC specification likely requires the downregulation of Dlx1/2 in their progenitor cells.

\section{Ascl1 function in OPC proliferation versus differentiation balance}

Even though Ascl1 is expressed in proliferating cells, its conditional deletion in OPCs increased proliferation as measured by Ki67 expression. This could result from the fact that Ascll activates target genes involved either in proliferation or in cell cycle exit depending on the context, as recently reported for neurogenesis (Castro et al., 2011). In OPCs, the presence of inhibitors, such as Id2/4 (Wang et al., 2001; Yun et al., 2004) and other cofactors involved in proliferation and differentiation, could balance Ascl1 activation of proliferation versus cell cycle exit. Supporting this hypothesis, Ascl1 genome-wide chromatin immunoprecipitation data (ChIP-seq) in purified OPCs suggest that Ascll binds regulatory regions of both positive and negative factors controlling cell cycle (Clavairoly A, Parras C, unpublished observations). Ascll deletion in OPCs also decreases differentiation during my- elination (postnatal) or remyelination (adult). Indeed, one or 2 weeks after Ascl1 deletion, more Ascl1-deficient cells are still OPCs and fewer have started differentiation. Our data suggest that Ascll cooperates with other factors to activate OPC differentiation and myelin protein expression. Nevertheless, Ascl1 requirement is compensated at later stages, and no myelination phenotype is found in Ascl1-mutant oligodendrocytes. Although Ascll is known to regulate $M B P$ transcription in vitro (Gokhan et al., 2005), a genome-wide analysis of Ascl1 targets in oligodendrogenesis will be important to identify the Ascl1-target genes involved in the different stages of oligodendrocyte development (specification, proliferation, division mode, differentiation, and myelination).

\section{Similar mechanisms of oligodendrogenesis during myelination and remyelination}

Demyelination has been shown to upregulate Olig2, Nkx2.2, and Sox10 transcript levels in and around lesion and also many other factors (Fancy et al., 2004, 2009), raising the question of the similarities and differences between oligodendrogenesis during myelination and remyelination. Our detailed characterization of the expression of Ascll and other TFs involved in oligodendrogenesis (Figs. 2 and 5) indicates that the same types of progenitors and OPCs, characterized by the same combined expression of markers, are involved in oligodendrogenesis during myelination and remyelination. After demyelination, we found that Ascll was upregulated in OPCs at levels found during myelination. Moreover, the levels of Ascl1, Olig2, Nkx2.2, and Sox9/10 expression at different stages of oligodendrogenesis were similar during remyelination and myelination (Fig. 5; and data not shown). Therefore, the upregulation of these factors during active remyelination likely results from the rejuvenation of a developmental genetic program enabling OPCs to actively proliferate, migrate, and differentiate into new remyelinating oligodendrocytes.

Demyelination induces axonal functional and structural loss, leading to major neurological and motor dysfunctions. In MS, despite the recent therapeutic advances aimed at reducing the inflammatory component and stopping demyelination, treatments to improve myelin repair are lacking because of the poor understanding of mechanisms leading to effective remyelination. In this context, our finding on the role of Ascll during myelin formation and in particular after demyelination, and future work characterizing its target genes, may pave the way toward a better understanding of the key players involved in oligodendrogenesis after demyelination and therefore help identifying new therapeutic targets aimed at favoring myelin repair.

\section{References}

Aguirre A, Dupree JL, Mangin JM, Gallo V (2007) A functional role for EGFR signaling in myelination and remyelination. Nat Neurosci 10:9901002. CrossRef Medline

Arnett HA, Fancy SP, Alberta JA, Zhao C, Plant SR, Kaing S, Raine CS, Rowitch DH, Franklin RJ, Stiles CD (2004) bHLH transcription factor Olig1 is required to repair demyelinated lesions in the CNS. Science 306: 2111-2115. CrossRef Medline

Bertrand N, Castro DS, Guillemot F (2002) Proneural genes and the specification of neural cell types. Nat Rev Neurosci 3:517-530. CrossRef Medline

Bhat RV, Axt KJ, Fosnaugh JS, Smith KJ, Johnson KA, Hill DE, Kinzler KW, Baraban JM (1996) Expression of the APC tumor suppressor protein in oligodendroglia. Glia 17:169-174. CrossRef Medline

Boda E, Viganò F, Rosa P, Fumagalli M, Labat-Gest V, Tempia F, Abbracchio MP, Dimou L, Buffo A (2011) The GPR17 receptor in NG2 expressing 
cells: focus on in vivo cell maturation and participation in acute trauma and chronic damage. Glia 59:1958-1973. CrossRef Medline

Boutin C, Diestel S, Desoeuvre A, Tiveron MC, Cremer H (2008) Efficient in vivo electroporation of the postnatal rodent forebrain. PLoS One 3:e1883. CrossRef Medline

Cai J, Zhu Q, Zheng K, Li H, Qi Y, Cao Q, Qiu M (2010) Co-localization of Nkx6.2 and Nkx2.2 homeodomain proteins in differentiated myelinating oligodendrocytes. Glia 58:458-468. CrossRef Medline

Casarosa S, Fode C, Guillemot F (1999) Mash1 regulates neurogenesis in the ventral telencephalon. Development 126:525-534. Medline

Castro DS, Martynoga B, Parras C, Ramesh V, Pacary E, Johnston C, Drechsel D, Lebel-Potter M, Garcia LG, Hunt C, Dolle D, Bithell A, Ettwiller L, Buckley N, Guillemot F (2011) A novel function of the proneural factor Ascll in progenitor proliferation identified by genome-wide characterization of its targets. Genes Dev 25:930-945. CrossRef Medline

Chen Y, Wu H, Wang S, Koito H, Li J, Ye F, Hoang J, Escobar SS, Gow A, Arnett HA, Trapp BD, Karandikar NJ, Hsieh J, Lu QR (2009) The oligodendrocyte-specific G protein-coupled receptor GPR17 is a cellintrinsic timer of myelination. Nat Neurosci 12:1398-1406. CrossRef Medline

Fancy SP, Zhao C, Franklin RJ (2004) Increased expression of Nkx2.2 and Olig2 identifies reactive oligodendrocyte progenitor cells responding to demyelination in the adult CNS. Mol Cell Neurosci 27:247-254. CrossRef Medline

Fancy SP, Baranzini SE, Zhao C, Yuk DI, Irvine KA, Kaing S, Sanai N, Franklin RJ, Rowitch DH (2009) Dysregulation of the Wnt pathway inhibits timely myelination and remyelination in the mammalian CNS. Genes Dev 23:1571-1585. CrossRef Medline

Franklin RJ, ffrench-Constant C (2008) Remyelination in the CNS: from biology to therapy. Nat Rev Neurosci 9:839-855. CrossRef Medline

Gokhan S, Marin-Husstege M, Yung SY, Fontanez D, Casaccia-Bonnefil P, Mehler MF (2005) Combinatorial profiles of oligodendrocyte-selective classes of transcriptional regulators differentially modulate myelin basic protein gene expression. J Neurosci 25:8311-8321. CrossRef Medline

Gorski JA, Talley T, Qiu M, Puelles L, Rubenstein JL, Jones KR (2002) Cortical excitatory neurons and glia, but not GABAergic neurons, are produced in the Emx1-expressing lineage. J Neurosci 22:6309-6314. Medline

Hack MA, Sugimori M, Lundberg C, Nakafuku M, Götz M (2004) Regionalization and fate specification in neurospheres: the role of Olig2 and Pax6. Mol Cell Neurosci 25:664-678. CrossRef Medline

Hall A, Giese NA, Richardson WD (1996) Spinal cord oligodendrocytes develop from ventrally derived progenitor cells that express PDGF alphareceptors. Development 122:4085-4094. Medline

Ivanova A, Nakahira E, Kagawa T, Oba A, Wada T, Takebayashi H, Spassky N, Levine J, Zalc B, Ikenaka K (2003) Evidence for a second wave of oligodendrogenesis in the postnatal cerebral cortex of the mouse. J Neurosci Res 73:581-592. CrossRef Medline

Kessaris N, Fogarty M, Iannarelli P, Grist M, Wegner M, Richardson WD (2006) Competing waves of oligodendrocytes in the forebrain and postnatal elimination of an embryonic lineage. Nat Neurosci 9:173-179. CrossRef Medline

Kitada M, Rowitch DH (2006) Transcription factor co-expression patterns indicate heterogeneity of oligodendroglial subpopulations in adult spinal cord. Glia 54:35-46. CrossRef Medline

Kondo T, Raff M (2000) Basic helix-loop-helix proteins and the timing of oligodendrocyte differentiation. Development 127:2989-2998. Medline

Lassmann H (1998) Neuropathology in multiple sclerosis: new concepts. Mult Scler 4:93-98. CrossRef Medline

Li H, de Faria JP, Andrew P, Nitarska J, Richardson WD (2011) Phosphorylation regulates OLIG2 cofactor choice and the motor neuronoligodendrocyte fate switch. Neuron 69:918-929. CrossRef Medline

Ligon KL, Fancy SP, Franklin RJ, Rowitch DH (2006) Olig gene function in CNS development and disease. Glia 54:1-10. CrossRef Medline

Liu Z, Hu X, Cai J, Liu B, Peng X, Wegner M, Qiu M (2007) Induction of oligodendrocyte differentiation by Olig2 and Sox10: evidence for reciprocal interactions and dosage-dependent mechanisms. Dev Biol 302:683693. CrossRef Medline

Lu QR, Cai L, Rowitch D, Cepko CL, Stiles CD (2001) Ectopic expression of Olig1 promotes oligodendrocyte formation and reduces neuronal survival in developing mouse cortex. Nat Neurosci 4:973-974. CrossRef Medline
Menn B, Garcia-Verdugo JM, Yaschine C, Gonzalez-Perez O, Rowitch D, Alvarez-Buylla A (2006) Origin of oligodendrocytes in the subventricular zone of the adult brain. J Neurosci 26:7907-7918. CrossRef Medline

Miguez A, Ducret S, Di Meglio T, Parras C, Hmidan H, Haton C, Sekizar S, Mannioui A, Vidal M, Kerever A, Nyabi O, Haigh J, Zalc B, Rijli FM, Thomas JL (2012) Opposing roles for Hoxa2 and Hoxb2 in hindbrain oligodendrocyte patterning. J Neurosci 32:17172-17185. CrossRef Medline

Mizuguchi R, Sugimori M, Takebayashi H, Kosako H, Nagao M, Yoshida S, Nabeshima Y, Shimamura K, Nakafuku M (2001) Combinatorial roles of Olig2 and neurogenin 2 in the coordinated induction of panneuronal and subtype-specific properties of motoneurons. Neuron 31:757-771. CrossRef Medline

Nait-Oumesmar B, Decker L, Lachapelle F, Avellana-Adalid V, Bachelin C, Baron-Van Evercooren A (1999) Progenitor cells of the adult mouse subventricular zone proliferate, migrate and differentiate into oligodendrocytes after demyelination. Eur J Neurosci 11:4357-4366. CrossRef Medline

Nait-Oumesmar B, Picard-Riera N, Kerninon C, Decker L, Seilhean D, Höglinger GU, Hirsch EC, Reynolds R, Baron-Van Evercooren A (2007) Activation of the subventricular zone in multiple sclerosis: evidence for early glial progenitors. Proc Natl Acad Sci U S A 104:4694-4699. CrossRef Medline

Nait-Oumesmar B, Picard-Riéra N, Kerninon C, Baron-Van Evercooren A (2008) The role of SVZ-derived neural precursors in demyelinating diseases: from animal models to multiple sclerosis. J Neurol Sci 265:26-31. CrossRef Medline

Pacary E, Heng J, Azzarelli R, Riou P, Castro D, Lebel-Potter M, Parras C, Bell DM, Ridley AJ, Parsons M, Guillemot F (2011) Proneural transcription factors regulate different steps of cortical neuron migration through Rndmediated inhibition of RhoA signaling. Neuron 69:1069-1084. CrossRef Medline

Parras CM, Galli R, Britz O, Soares S, Galichet C, Battiste J, Johnson JE, Nakafuku M, Vescovi A, Guillemot F (2004) Mash1 specifies neurons and oligodendrocytes in the postnatal brain. EMBO J 23:4495-4505. CrossRef Medline

Parras CM, Hunt C, Sugimori M, Nakafuku M, Rowitch D, Guillemot F (2007) The proneural gene Mash1 specifies an early population of telencephalic oligodendrocytes. J Neurosci 27:4233-4242. CrossRef Medline

Petryniak MA, Potter GB, Rowitch DH, Rubenstein JL (2007) Dlx1 and Dlx2 control neuronal versus oligodendroglial cell fate acquisition in the developing forebrain. Neuron 55:417-433. CrossRef Medline

Qi Y, Cai J, Wu Y, Wu R, Lee J, Fu H, Rao M, Sussel L, Rubenstein J, Qiu M (2001) Control of oligodendrocyte differentiation by the Nkx2.2 homeodomain transcription factor. Development 128:2723-2733. Medline

Rivers LE, Young KM, Rizzi M, Jamen F, Psachoulia K, Wade A, Kessaris N, Richardson WD (2008) PDGFRA/NG2 glia generate myelinating oligodendrocytes and piriform projection neurons in adult mice. Nat Neurosci 11:1392-1401. CrossRef Medline

Scott CE, Wynn SL, Sesay A, Cruz C, Cheung M, Gomez Gaviro MV, Booth S, Gao B, Cheah KS, Lovell-Badge R, Briscoe J (2010) SOX9 induces and maintains neural stem cells. Nat Neurosci 13:1181-1189. CrossRef Medline

Soriano P (1999) Generalized lacZ expression with the ROSA26 Cre reporter strain. Nat Genet 21:70-71. CrossRef Medline

Spassky N, Goujet-Zalc C, Parmantier E, Olivier C, Martinez S, Ivanova A, Ikenaka K, Macklin W, Cerruti I, Zalc B, Thomas JL (1998) Multiple restricted origin of oligodendrocytes. J Neurosci 18:8331-8343. Medline

Srinivas S, Watanabe T, Lin CS, William CM, Tanabe Y, Jessell TM, Costantini F (2001) Cre reporter strains produced by targeted insertion of EYFP and ECFP into the ROSA26 locus. BMC Dev Biol 1:4. CrossRef Medline

Staugaitis SM, Trapp BD (2009) NG2-positive glia in the human central nervous system. Neuron Glia Biol 5:35-44. CrossRef Medline

Stolt CC, Lommes P, Sock E, Chaboissier MC, Schedl A, Wegner M (2003) The Sox 9 transcription factor determines glial fate choice in the developing spinal cord. Genes Dev 17:1677-1689. CrossRef Medline

Stolt CC, Lommes P, Friedrich RP, Wegner M (2004) Transcription factors Sox8 and Sox10 perform non-equivalent roles during oligodendrocyte development despite functional redundancy. Development 131:2349 2358. CrossRef Medline

Sugiarto S, Persson AI, Munoz EG, Waldhuber M, Lamagna C, Andor N, 
Hanecker P, Ayers-Ringler J, Phillips J, Siu J, Lim DA, Vandenberg S, Stallcup W, Berger MS, Bergers G, Weiss WA, Petritsch C (2011) Asymmetry-defective oligodendrocyte progenitors are glioma precursors. Cancer Cell 20:328-340. CrossRef Medline

Sugimori M, Nagao M, Bertrand N, Parras CM, Guillemot F, Nakafuku M (2007) Combinatorial actions of patterning and HLH transcription factors in the spatiotemporal control of neurogenesis and gliogenesis in the developing spinal cord. Development 134:1617-1629. CrossRef Medline

Sun T, Echelard Y, Lu R, Yuk DI, Kaing S, Stiles CD, Rowitch DH (2001) Olig bHLH proteins interact with homeodomain proteins to regulate cell fate acquisition in progenitors of the ventral neural tube. Curr Biol 11: 1413-1420. CrossRef Medline

Tekki-Kessaris N, Woodruff R, Hall AC, Gaffield W, Kimura S, Stiles CD, Rowitch DH, Richardson WD (2001) Hedgehog-dependent oligodendrocyte lineage specification in the telencephalon. Development 128: 2545-2554. Medline

Vierbuchen T, Wernig M (2012) Molecular roadblocks for cellular reprogramming. Mol Cell 47:827-838. CrossRef Medline

Vierbuchen T, Ostermeier A, Pang ZP, Kokubu Y, Südhof TC, Wernig M (2010) Direct conversion of fibroblasts to functional neurons by defined factors. Nature 463:1035-1041. CrossRef Medline

Waclaw RR, Wang B, Pei Z, Ehrman LA, Campbell K (2009) Distinct temporal requirements for the homeobox gene Gsx2 in specifying striatal and olfactory bulb neuronal fates. Neuron 63:451-465. CrossRef Medline
Wang S, Sdrulla A, Johnson JE, Yokota Y, Barres BA (2001) A role for the helix-loop-helix protein Id2 in the control of oligodendrocyte development. Neuron 29:603-614. CrossRef Medline

Watanabe M, Hadzic T, Nishiyama A (2004) Transient upregulation of $\mathrm{Nkx}$ 2.2 expression in oligodendrocyte lineage cells during remyelination. Glia 46:311-322. CrossRef Medline

Yue T, Xian K, Hurlock E, Xin M, Kernie SG, Parada LF, Lu QR (2006) A critical role for dorsal progenitors in cortical myelination. J Neurosci 26:1275-1280. CrossRef Medline

Yun K, Mantani A, Garel S, Rubenstein J, Israel MA (2004) Id4 regulates neural progenitor proliferation and differentiation in vivo. Development 131:5441-5448. CrossRef Medline

Zhou Q, Anderson DJ (2002) The bHLH transcription factors OLIG2 and OLIG1 couple neuronal and glial subtype specification. Cell 109: 61-73. CrossRef Medline

Zhou Q, Choi G, Anderson DJ (2001) The bHLH transcription factor Olig2 promotes oligodendrocyte differentiation in collaboration with $\mathrm{Nkx2.2}$. Neuron 31:791-807. CrossRef Medline

Zhu X, Hill RA, Dietrich D, Komitova M, Suzuki R, Nishiyama A (2011) Age-dependent fate and lineage restriction of single NG2 cells. Development 138:745-753. CrossRef Medline

Zhu X, Zuo H, Maher BJ, Serwanski DR, LoTurco JJ, Lu QR, Nishiyama A (2012) Olig2-dependent developmental fate switch of NG2 cells. Development 139:2299-2307. CrossRef Medline 